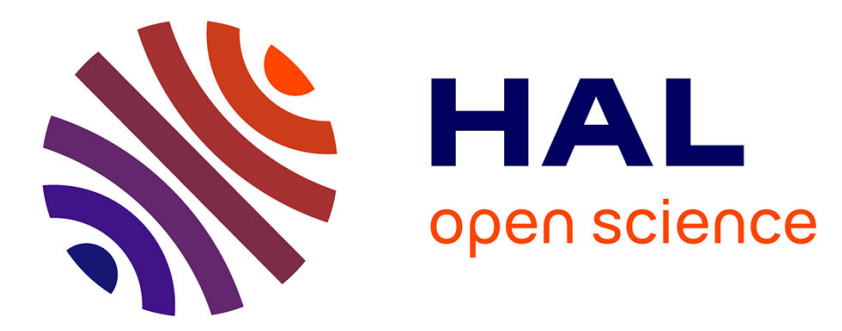

\title{
The use of historical cartography and ALS technology to map the geomorphological changes of volcanic areas: A case study from Gran Cono of Somma-Vesuvius volcano
}

\author{
M. Bisson, Alessandro Tadini, R. Gianardi, A. Angioletti
}

\section{- To cite this version:}

M. Bisson, Alessandro Tadini, R. Gianardi, A. Angioletti. The use of historical cartography and ALS technology to map the geomorphological changes of volcanic areas: A case study from Gran Cono of Somma-Vesuvius volcano. Geomorphology, 2021, 380, pp.107624. 10.1016/j.geomorph.2021.107624 . hal-03188752

\author{
HAL Id: hal-03188752 \\ https://hal.uca.fr/hal-03188752
}

Submitted on 2 Apr 2021

HAL is a multi-disciplinary open access archive for the deposit and dissemination of scientific research documents, whether they are published or not. The documents may come from teaching and research institutions in France or abroad, or from public or private research centers.
L'archive ouverte pluridisciplinaire HAL, est destinée au dépôt et à la diffusion de documents scientifiques de niveau recherche, publiés ou non, émanant des établissements d'enseignement et de recherche français ou étrangers, des laboratoires publics ou privés.

\section{(ㅇ)(1) $\$$}

Distributed under a Creative Commons Attribution - NonCommercial - NoDerivatives| 4.0 


\section{Journal Pre-proof}

The use of historical cartography and ALS technology to map the geomorphological changes of volcanic areas: a case study from Gran Cono of Somma-Vesuvius volcano

M. Bisson, A. Tadini, R. Gianardi, A. Angioletti

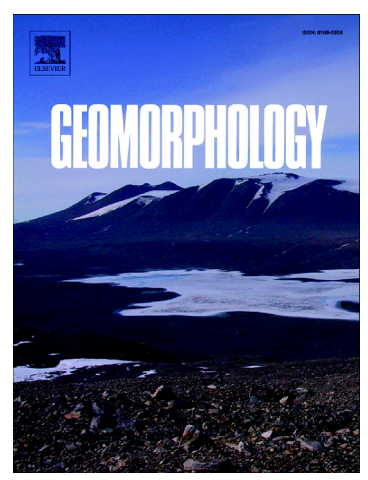

PII: S0169-555X(21)00032-5

DOI: https://doi.org/10.1016/j.geomorph.2021.107624

Reference:

GEOMOR 107624

To appear in:

Geomorphology

Received date:

18 August 2020

Revised date:

19 January 2021

Accepted date:

24 January 2021

Please cite this article as: M. Bisson, A. Tadini, R. Gianardi, et al., The use of historical cartography and ALS technology to map the geomorphological changes of volcanic areas: a case study from Gran Cono of Somma-Vesuvius volcano, Geomorphology (2021), https://doi.org/10.1016/j.geomorph.2021.107624

This is a PDF file of an article that has undergone enhancements after acceptance, such as the addition of a cover page and metadata, and formatting for readability, but it is not yet the definitive version of record. This version will undergo additional copyediting, typesetting and review before it is published in its final form, but we are providing this version to give early visibility of the article. Please note that, during the production process, errors may be discovered which could affect the content, and all legal disclaimers that apply to the journal pertain.

(C) 2021 Published by Elsevier. 


\title{
The use of historical cartography and ALS technology to map the geomorphological changes of volcanic areas: a case study from Gran Cono of Somma-Vesuvius volcano
}

\author{
M. Bisson ${ }^{1, *}$, A. Tadini ${ }^{2}$, R. Gianardi ${ }^{1}$, A. Angioletti ${ }^{3}$
}

${ }^{1}$ Istituto Nazionale di Geofisica e Vulcanologia, Sezione di Pisa, via Cesare Battisti 53, 56125 Pisa, Italy

2 Laboratoire Magmas et Volcans, Université Clermont Auvers ... LNRS, IRD, OPGC, Campus Universitaire des Cézeaux, 6 Avenue Blaise Pascal, 63178 Aubiere Ce'`ex. France

${ }^{3}$ Università degli Studi di Pisa, via Santa Maria 53, 56100 Pisa, I al,

*Corresponding author: marina.bisson@ingv.it

\begin{abstract}
The eruptive activity of a volcano modil: $\mathrm{s}$ lıs surface topography through morphological changes generated by the deposition of em ttea volcanic material and resulting gravity-driven processes, which can form accumulation oi material in addition to the most common erosional phenomena. Mapping and quantifying : uch morphological changes allow to derive new data useful to better describe and understand the eruptive history of the volcano itself. Nowadays, one of the mostly used method to identify such morphological changes consists of comparing Digital Elevation Models (DEM) of the volcanic area before and after an eruptive event. If the eruptive event is referred to periods prior to 1980's , the only method to reproduce DEMs consists of elaborating the historical cartography that is often available only in paper format. In this work we aim to prove the reliability of this approach, presenting a study on the morphological changes (from 1876 to 1944) of the summit caldera of the Somma - Vesuvio volcano (Italy). For the first time, we compare DEMs derived from historical maps (1876, 1906 and 1929) and a DEM dated 2012 obtained by remote
\end{abstract}


sensing. The four models of the caldera, digitally reproduced at the same spatial resolution, are morphologically investigated through specific maps derived from the DEMs and a set of height profiles. In addition, further morphometric analyses and accurate quantifications in volume and surface are presented and discussed for a portion of the Somma-Vesuvio summit caldera, represented by the Gran Cono edifice. Considering the different typology of the source data used in this study, it is also provided a discussion on the respective accuracies that, especially for the historical maps, represent a crucial point for obtaining DEMs able to reproduce topographies more realistic as possible. For this reason, despite data source were prnes ad following rigours criteria, the calculations of volume, surface and distance related the morphological changes of the volcano are associated to an accurate quantification of the sror. Following this, the main results obtained in this study are: i) the identification of several pa ${ }^{+}$volcanic deposits and the estimation of the related thicknesses, both in good agreement $w: n$ ublished literature; ii) the quantification of the morphological changes of the Gran $\mathrm{Co}$. f f.om 1876 to 1944 resulting in a volume and surface growth of $133 \times 10^{6} \mathrm{~m}^{3}( \pm 5 \%)$ and $\sim 0.1^{1} \mathrm{~km}^{2}$, respectively; iii) the identification of a possible migration path of the centroid of the $\left(r_{n} \cap\right.$ Cono crater along the SW-NE preferential direction during the investigated period.

Keywords: Digital Elevation Model, Historical Cartography, Airborne Laser Scanning technology, Somma - Vesuvio volcano, Morphological Changes Quantifications 


\section{INTRODUCTION}

In the last 40 years, the topographies of an active volcano have been digitally reproduced with spatial resolutions and accuracies ranging from several meters to some tens of centimeters by using traditional methodologies based on digitalization of contour lines and elevation points from raster cartography (Favalli et al., 1999, Tarquini et al., 2007) and more innovative techniques from remote sensing (Wu, 1979; Ferretti et al, 1999; Garvin et al., 2018). In the last two decades, specific remote sensing techniques such as airborne laser scanning (ALS), aerial stereo photogrammetry combined with SfM (Structure from Motion) elaboration, and satellite ster o p otogrammetry, result to be the most diffused to create Digital Elevation Model (DEM) in vc'can c areas (Pesci et al., 2007; James and Robson, 2012; Jones et al., 2015; Bisson et al., 2016; Mı ller et al., 2017; Beyer et al., 2018; De Beni et al., 2019). Such models, properly analrad and compared, allowed i) to study the morphology of the same volcano in different tim ? (Neri et al., 2008), ii) to produce a series of data useful to better document and understand the ruptive history of the volcano itself (Marsella et al., 2012; Dai and Howat 2017; Whelley et..1., 2017, Ganci et al., 2018) and iii) to simulate volcanic phenomena and their impact on the cen *ory producing maps useful to mitigate the hazard and risk

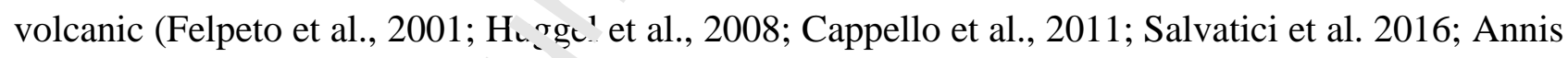
et al, 2020). The morpholos y $\iota^{c}$ a volcano before the 1980's cannot be obviously reproduced with the previously mentioned emote sensing techniques and hereupon the available historical cartography, with all its limits (Balletti, 2000), becomes the only reference data. The main volcanoes in Italy, Mt. Etna in Sicily and Somma-Vesuvio (SV) and Campi Flegrei in Campania, are characterized by a large amount of historical drawings and illustrations that often show an approximate representation of the territory during a particular eruptive event. Most of the oldest representations related to the three volcanoes date back to the $16^{\text {th }}$ and $17^{\text {th }}$ centuries (Naddeo, 2004; Branca and Abate, 2017). As regards SV, the first topographic map reproducing the entire area of the volcano with a reference of geographic coordinates dates back to the second half of $19^{\text {th }}$ century, and was produced by the "Allievi of the Istituto Topografico Militare" during the 1875-1876 
(Palmentieri, 2016), whereas for smaller areas some cartographies were already produced during the second half of $18^{\text {th }}$ century (Ronza, 2017). During the $20^{\text {th }}$ century, the cartography of SV area, as well as for the entire national territory, started to be produced by IGM (Istituto Geografico Militare), that became the main reference for the cartography in Italy. Up to now, IGM has reproduced the entire Italian territory at different scales $(1: 25,000,1: 50,000,1: 100,000,1: 250,000)$ through aerial photogrammetry. At the beginning, the cartography has been produced in the Roma 40 reference system, and subsequently, starting from the 1980's, firstly in the ED 50 and finally in the WGS84 (www.igmi.org) reference systems. Nowadays, the mo+ detailed reproductions of a territory, or its portion, are obtained by elaborating ALS dat $\cdot v_{1}$ by coupling the SfM technique to the UAV (Unmanned Aerial Vehicle) photogrammetry Su-h systems allow to reproduce at high spatial resolution and accuracy (few tens of $\mathrm{cm}$ ) all the teatures (natural and anthropic) of the territory. In this work, which extends the prelim in rv work of Bisson et al. (2020) by presenting new data and further analyses, we present a stu dy that compares the topographies of a volcanic area through time, and derived from very diffe ^nt sources (historical cartography and ALS acquisition). The aim of this work is firstly to demnns ${ }^{r}$.te that the historical topographic maps, if processed and elaborated with rigours criteria, a.' $\mathrm{ow}$ to derive reliable information for quantifying morphological changes of volcanic areas befor the 1980's. In particular, this paper documents and analyses the morphological changes be veul 1876 and 1944 of SV (Fig.1), one of the most hazardous volcanoes in the world, not only for the very high population density (up to 50,000 inhabitants $/ \mathrm{km}^{2}$ - ISTAT, 2011) of its surroundings, but also for the extreme variability of its eruptive style, capable of producing large-magnitude explosive eruptions (Cioni et al., 2008). 


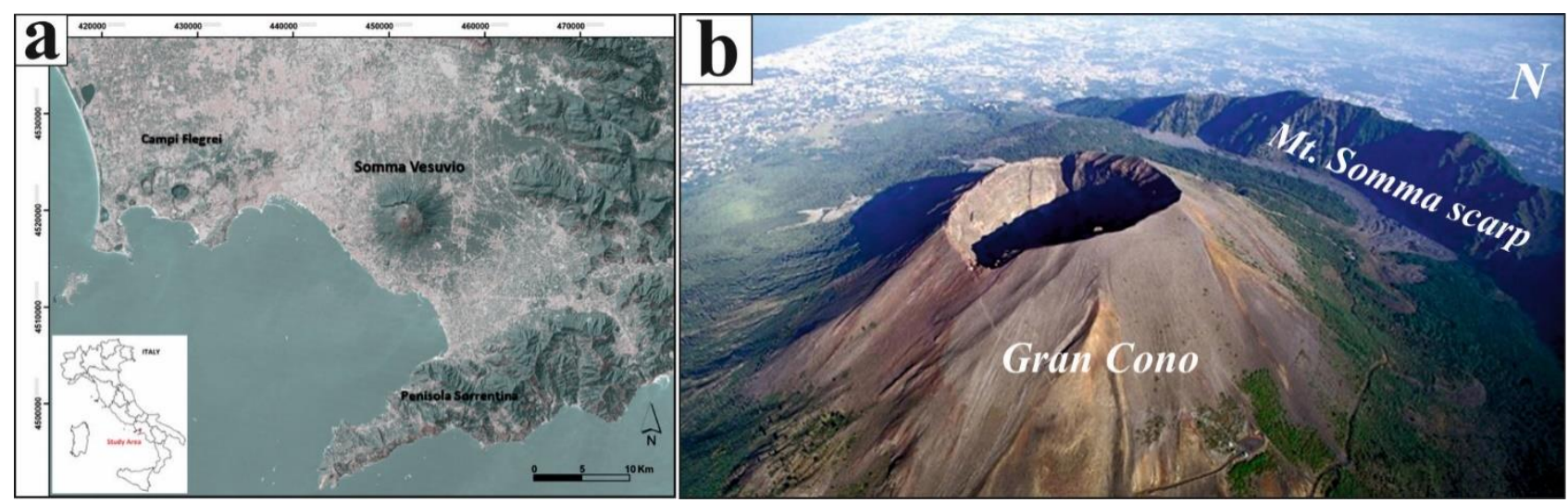

Figure 1 - The study area: a) A Landsat 7-ETM image of the Camranian plain including the Somma Vesuvio (SV) volcano. The coordinates are expressed in the UTM WGSí: $33 \mathrm{~N}$ reference coordinate system; b) aerial image of SV volcano with the city of Naples in the backgrour $\lrcorner$.

As regards the 3D digital reproduction of past topographies $4 \mathrm{~s} \mathrm{~V}$, in literature we found only two works. The first work (Favalli and Pareschi, 2004) rernns. -ucts at different time frames (1900, 1906, 1920 and 1988) the DEM of a portion of the SV cu "esponding to the current "Gran Cono" edifice with the aim to test the "DEST" algori $h_{\llcorner.,}$, variant of Delaunay triangulation able to improve the TIN construction and consequ ${ }^{n^{4}} \wedge$ y, the morphology reproduction. The second work (Ventura and Vilardo, 2008) reconstructs ti- 3D model of the 1944 lava flow from ALS data with a spatial resolution of $0.33 \mathrm{~m}$. This wary 'igh resolution allowed a very detailed morphological representation of the flow itself $u_{\llcorner}$, ful to infer some emplacement mechanisms as well. Differently from these two works, we prnpu a multi-temporal study to document the topography changes at SV over the past century. $\mathrm{V} / \mathrm{e}$ reconstruct the topographies by using historical maps and elevation data acquired by remote sensing techniques. In detail, the DEMs reproduce the entire caldera zone that will be analysed through specific maps and a set of height profiles, while the estimations in area and volume of the morphological changes are referred to a specific zone, common to all DEMs, identified with the "Gran Cono" edifice. The caldera zone and Gran Cono edifice investigated in this work are defined according to Tadini et al. (2017). After a brief description of the geological and volcanological setting of the study area, we will present the source data and the derived DEMs associated to a quantification of the plane-altimetry errors. Then, the results obtained from the morphological analyses will be described and discussed pointing out the main critical issues and the 
possible implications with the geo-volcanological aspects. Finally, we will conclude summarizing the main remarks.

\section{GEO-VOLCANOLOGICAL SETTING}

Somma-Vesuvio (SV) is a relatively young composite volcano of moderate altitude ( 1200 m a.s.1.) located in the Campanian Plain (Central Italy) between the Campi Flegrei volcano and the Penisola Sorrentina (Fig. 1a). Its oldest products postdate the Campanian 'snimbrite deposit of the nearby Campi Flegrei volcano (39 ka BP; Cioni et al., 2008), and are r latf $\mathbb{d}$ to the first eruptive phase of the volcano. During this latter ( $\sim 39-22 \mathrm{ka} \mathrm{BP}$; Sbrana et al, $2 \geq \mathrm{n})$, effusive activity resulted in the accumulation of thick piles of lava flows and scoria de ${ }_{\mathrm{r}}$ ssits, which built up the $\sim 1900 \mathrm{~m}$ high Mt. Somma (Cioni et al., 1999). Such edifice has bef $n$ prrtially dismantled by four large-magnitude eruptions, starting from the Pomici di Base ' 11. ia. eruption of $\sim 22$ ka BP (Bertagnini et al., 1998; Santacroce et al., 2008) up to the world-famou AD 79 Plinian eruption (Sigurdsson et al., 1985). This intense explosive activity punct $a^{t}={ }^{1}$ the last $20 \mathrm{ka}$, it produced thick tephra fallout and pyroclastic density currents deposi and developed the characteristic summit caldera of the SV

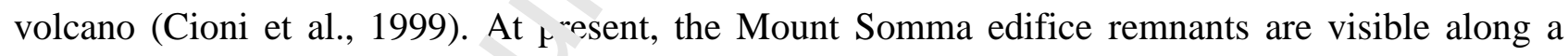
morphological scarp (farin of the edifice and along d^esly incised valley on the northern part of the volcano (Santacroce and Sbrana, 2003; Sbrana et al. 2020). The Gran Cono (or Vesuvio sensu stricto - Fig. 1b) edifice started to grow within the summit caldera partially after the AD 79 eruption, and more substantially after the AD 472 sub-Plinian eruption (Cioni et al., 1999). Such growth occurred in consequence of effusive to mild explosive activity during period of open conduit conditions, which have been at least 4 after the AD 79 eruption (Cioni et al., 2008). The latter period with open conduit conditions started with the AD 1631 sub-Plinian eruption (Rosi et al., 1993) and lasted from 1631 to 1944. Since the last VEI 3 eruption of AD 1944 (Cole and Scarpati, 2010), SV is considered dormant in a 
closed conduit condition (Scandone et al., 2008). In general, during an open conduit period at SV, eruptions are mostly characterized by non-stationary strombolian activity where magma is in a shallow magma chamber (Scandone et al., 2008). When a new batch of magma arrives into the shallow conduit filling it, magma could either overflow in gentle lava effusion or, in case of higher inputs, generate larger magnitude, violent strombolian eruptions (e.g. the 1906 eruption; Bertagnini et al., 1991; Scandone et al., 2008). When these latter eruptions occur, the shallower magmatic system tends to be evacuated, and the successive new magma batches result in a reappraisal of the non-stationary strombolian activity (Scandone et al., 2008). Dיritic the period 1631-1944, the numerous historical accounts and the abundance of studied de pu its allowed to reconstruct precisely the volcanic history of this last period of activity (Scana ne et al., 1993; Arrighi et al., 2001; Principe et al., 2004; Cioni et al., 2008; Scandone et al. 24 18): Table 1 summarizes all the eruptive events occurred in the years 1876-1944, correspr $n^{\prime} n^{n}$, to the period investigated in this work. For each eruptive event, the table reports the da a $r$. beginning and end, the duration of event expressed in days, eruptive typology, the volume of c -Ipted products and the Volcanic Explosive Index (VEI).

Table 1- Summary of SV volcanic e cup: ins in the period 1876-1944

\begin{tabular}{|c|c|c|c|c|c|}
\hline $\begin{array}{c}\text { Beginning } \\
\text { (dd/mm/yyyy) }\end{array}$ & \begin{tabular}{|c} 
Enc' \\
$\left(\mathrm{dd} / \mathrm{m}^{\prime}{ }_{2}, \mathrm{vyy}\right)$
\end{tabular} & $\begin{array}{c}\text { Length } \\
\text { (days) }\end{array}$ & Type $^{\mathbf{a}}$ & $\begin{array}{c}\text { Deposit } \\
\text { volume }\left(\mathbf{m}^{3}\right)\end{array}$ & VEI \\
\hline $16 / 12 / 1881$ & $31 \mathrm{~N}^{1} / \overline{\mathrm{QQ}}$ & 776 & $\mathrm{~S}+\mathrm{LF}$ & n.a. & $1-2$ \\
\hline 02/05/1885 & $01 / 07 / 1386$ & 425 & $\mathrm{~S}+\mathrm{LF}$ & n.a. & 1 \\
\hline $16 / 04 / 1887$ & $19 / 04 / 1887$ & 3 & $\mathrm{~S}+\mathrm{LF}$ & n.a. & 1 \\
\hline 01/05/1889 & $30 / 09 / 1889$ & 152 & $\mathrm{~S}+\mathrm{LF}$ & n.a. & 1 \\
\hline 07/06/1891 & 03/06/1894 & 1092 & $\mathrm{LF}$ & $3.6 \times 10^{7}$ (lava) & 2 \\
\hline 03/07/1895 & $07 / 09 / 1899$ & 1527 & LF & $1 \times 10^{8}$ (lava) & 2 \\
\hline 27/08/1903 & 30/09/1904 & 400 & $\mathrm{~S}+\mathrm{LF}$ & $5 \times 10^{5}$ (lava) & 2 \\
\hline 03/02/1906 & $03 / 04 / 1906$ & 59 & $\mathrm{~S}+\mathrm{LF}$ & $1.8 \times 10^{6}$ (lava) & 1 \\
\hline 04/04/1906 & 22/04/1906 & 18 & VS+LF & $\begin{array}{l}2 \times 10^{7} \text { (lava) } \\
7.1 \times 10^{7} \\
\text { (tephra) }\end{array}$ & $3-4$ \\
\hline 27/11/1926 & 28/11/1926 & 1 & $\mathrm{~S}+\mathrm{LF}$ & n.a. & 1 \\
\hline 01/08/1927 & $02 / 08 / 1927$ & 1 & $\mathrm{~S}+\mathrm{LF}$ & n.a. & 1 \\
\hline 11/08/1928 & $12 / 08 / 1928$ & 1 & $\mathrm{~S}+\mathrm{LF}$ & n.a. & 1 \\
\hline 03/06/1929 & $08 / 06 / 1929$ & 5 & $\mathrm{~S}+\mathrm{LF}$ & $1.2 \times 10^{7}$ (lava) & $2-3$ \\
\hline
\end{tabular}




\begin{tabular}{|l|l|l|l|l|l|}
$11 / 07 / 1930$ & $30 / 07 / 1930$ & 19 & S+LF & n.a. & 1 \\
$02 / 10 / 1930$ & $09 / 11 / 1930$ & 38 & S+LF & n.a. & 1 \\
$01 / 06 / 1933$ & $19 / 11 / 1934$ & 536 & S+LF & n.a. & $1-2$ \\
$12 / 02 / 1935$ & $31 / 03 / 1935$ & 47 & S+LF & n.a. & 1 \\
$08 / 07 / 1935$ & $21 / 08 / 1935$ & 44 & S+LF & n.a. & 1 \\
$28 / 03 / 1936$ & $24 / 09 / 1936$ & 180 & S+LF & n.a. & 1 \\
$04 / 06 / 1937$ & $07 / 07 / 1937$ & 33 & S+LF & n.a. & 0 \\
$08 / 08 / 1939$ & $09 / 08 / 1939$ & 1 & S+LF & n.a. & 0 \\
$26 / 06 / 1940$ & $31 / 07 / 1940$ & 35 & S+LF & n.a. & 0 \\
$22 / 10 / 1941$ & $15 / 12 / 1942$ & 419 & S+LF & n.a. & $1-2$ \\
$06 / 01 / 1944$ & $23 / 02 / 1944$ & 48 & S+LF & n.a. & 0 \\
$18 / 03 / 1944$ & $04 / 04 / 1944$ & 17 & VS+LF & $2 \times 10^{7}($ lava) & \\
& & & & (tephr. & 3 \\
\hline
\end{tabular}

${ }^{\mathrm{a} T y p e: ~} \mathrm{~S}$ - Strombolian activity; LF - Lava Flow; VS - Violent Stror boli $\mathrm{n}$ eruption. The type comes from Scandone et al. (2008) with integrations from Arrighi et al. (2001) na Toni et al. (2008).

\section{CONSTRUCTION OF DEMS FROM HISTON 'CAL MAPS AND ALS DATA}

The data source and the methodologies used tc recuistruct the topographies assumed by the SV summit caldera during the last century a* presented in the two following sub-sections: i) Topography from historical maps; ii) Top `raphy from Airborne Laser Scanning (ALS). In both cases, the ESRI GIS platform was 'œ ${ }^{\prime}$ as main working environment to process source data and reconstruct the topography mnde's, whereas specific software such as Tn-ShArc (Terranova platform), CartLab 2.0 anr. Traspunto (www.igmi.org) are used to uniform the cartographic reference system of all data, fundamental requirement for analysing and comparing geo-spatial data in GIS environment. In this study, all data are managed in the WGS84 UTM 33N cartographic reference system.

\subsection{Topography from historical Maps}

The 3D SV topographies of $19^{\text {th }}$ and $20^{\text {th }}$ century were reproduced starting from IGM historical maps that contain geographic references in latitude and longitude, generally placed at the boundary of the maps themselves. These references are fundamental to assign to the map, in raster format, the 
spatial coordinates and subsequently extract in geo-referenced digital vector formats (points, polylines, polygons) the 3D topographic information necessary to create the DEM. The historical maps used to reproduce the topography of SV summit caldera are referred to the 1876,1906 and 1929 years (Fig. 2a,b,d); moreover, a supplementary map dated 1920 and centred on the crater area (Fig. 2c) was used specifically to better constrain the crater rim outline evolution.

The four maps, selected among those available, show the topography of the volcano before and immediately after the main eruptive events occurred from 1876 , 1944 covering a total period of about 50 years. The 1876 map corresponds to sheet $n^{\circ} 184$ of th Ca ta d'Italia produced by IGM at scale 1:50,000 with contours lines every $10 \mathrm{~m}$. This map allo s tr reconstruct the topography of the SV summit caldera before two eruptive events occurrec in '891-94 and 1895-99, respectively (see Table 1). These events created two volcanic structros, "Colle Margherita" and "Colle Umberto", named "dome-shaped accumulations of the lava flows" by Arrighi et al. (2001) and "exhogenous

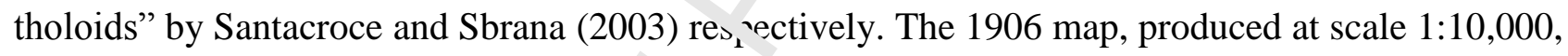
updates the topography of the volcano sArr lie violent eruption of April 1906 (Table 1), considered the strongest event of the $20^{\text {th }}$ cen ury hecause it heavily modified the morphology of the Gran Cono (Bertagnini et al., 1991). With the aim of obtaining a detailed reconstruction of the SV summit caldera after this ,tro'g eruptive event, the 1906 map was produced by reporting the contours lines every $5 \mathrm{~m}$ (in ;tead of $10 \mathrm{~m}$ ). The 1920 map, instead, provides a detailed outline of the Gran Cono crater rim during a period of intense intra-crateric activity (Scandone et al., 2008) before the June 1929 eruption. Finally, the 1929 map, produced at scale 1:25,000, delineates the topography before the 1944 eruption (Cole and Scarpati, 2010) reporting not only the topography of the volcano and its crater, but also portions of surrounding areas after the June 1929 eruption. 

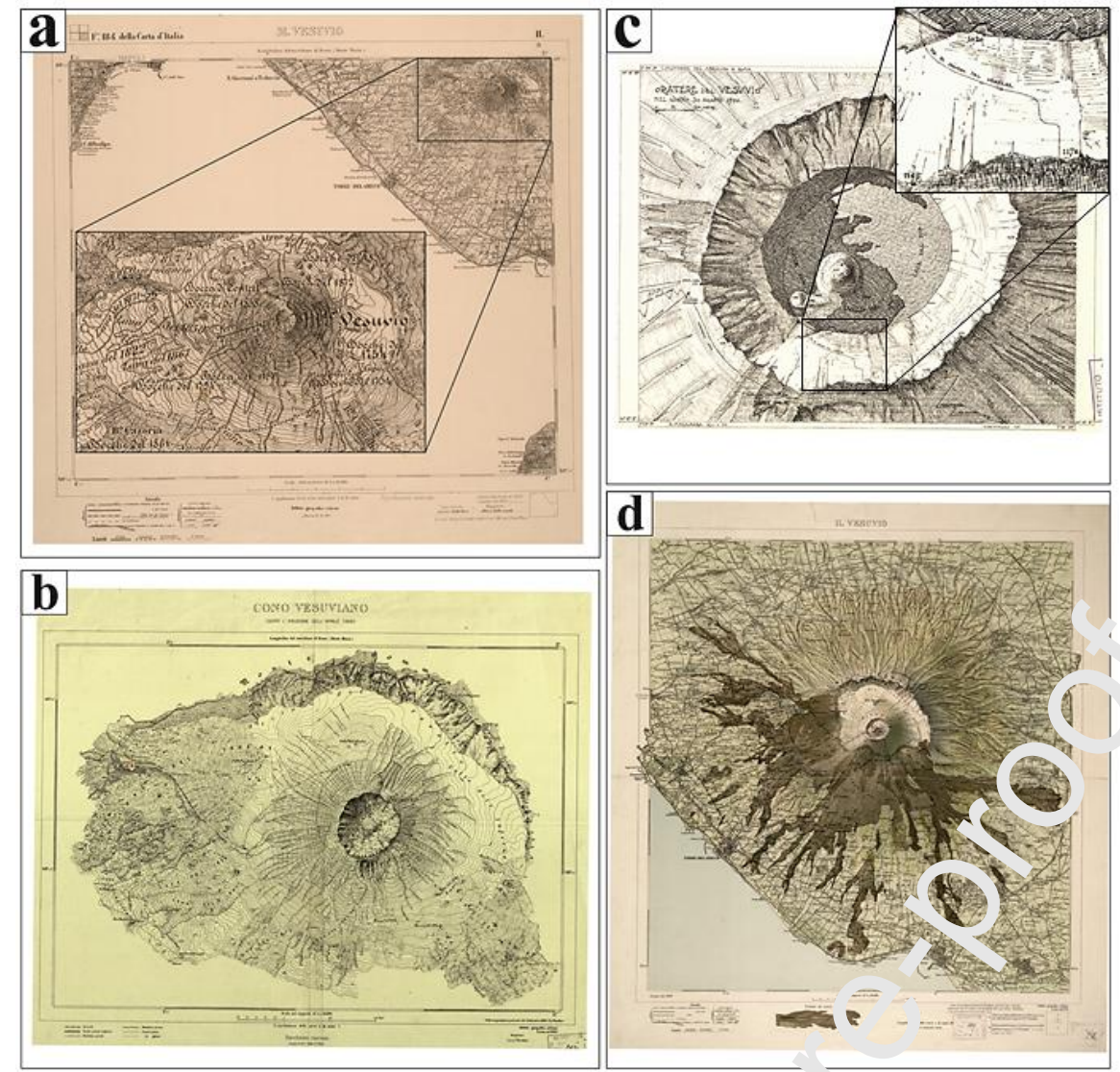

Figure 2 - IGM historical maps. a) 1876; b) 1906; 、) 1920; d) 1929. In the inset of 2c it is possible to read the highest points of the 1920 crater rim. The. 'aps are provided by IGM in agreement with the authorization $\mathrm{n}^{\circ} 0013597$ dated 24/09/2019.

All the four maps were acquired $\iota_{\text {: }}$ scanning the original paper at a resolution of $300 \mathrm{dpi}$ and the outputs were stored in 8-bit ra rar format (grey tones). The high resolution allowed to better reproduce the cartographic $\iota^{\prime} \mathrm{ements}$ (contour lines and height points) indispensable for our purpose, whereas grey tones highlighted some morphological details (i.e. very steep slopes, gullies, edges and others) that, inserted in the interpolation procedure, improved the resulting DEM. The scanning procedure was made by using a plane scanner to limit the deformation errors as much as possible. Subsequently, the obtained raster maps were geo-referenced by using the ground control points method (De Leeuw et al., 1988). In particular, for each raster, 8 points were selected in order to satisfy the following requirements: i) obtaining a spatial distribution of the points in order to cover in homogenous mode the entire image; ii) selecting the points rigorously either in the geographic grid reported as the map boundary or, when not possible, in some details or features well 
recognizable both in the historical maps and in the nowadays cartographies geo-coded in the WGS 84 UTM 33N reference cartographic system. The original latitude and longitude coordinates, expressed in degrees according to Roma 40 System and readable on the boundary of the historical maps, were transformed in 8 points geo-referenced in the WGS 84 UTM 33N metric system through the software Traspunto (www.igmi.org), that assures an error of positioning $<1 \mathrm{~m}$ (Travaglini, 2004). Subsequently the 8 points were used in the geo-referencing procedure based on the affine transformation and performed on the TN-ShArc platform (https://www.agros.it/softwareterranova). In detail, after the transformation, the procedure colcuintes the RMSE (Root Mean Square Error) and if this latter results $<2$ pixel, the final ge -referenced map is automatically memorized according to the raster format selected by the ils $r$. In this study, the output maps were stored in TIFF format. Finally, by digitizing the elevtı data in line and point vector formats (shapefile), for each historical map two 3D dita ts were created and used to reconstruct the topography of the caldera zone related tc th $f$ 1876, 1906 and 1929 years. By interpolating the datasets with the Delaunay algorithm ( $S_{1} \cdot{ }^{3}$ wchuk, 2002), three elevation vector models stored in ESRI TIN format were produced and the onverted in ESRI GRID format with a spatial resolution of $5 \mathrm{~m}$, a value coherent with thi orlyinal scale of the source maps. Figure 3a-c shows the three morphologies of the past throngi the Shaded Relief map derived from the respective DEMs. 

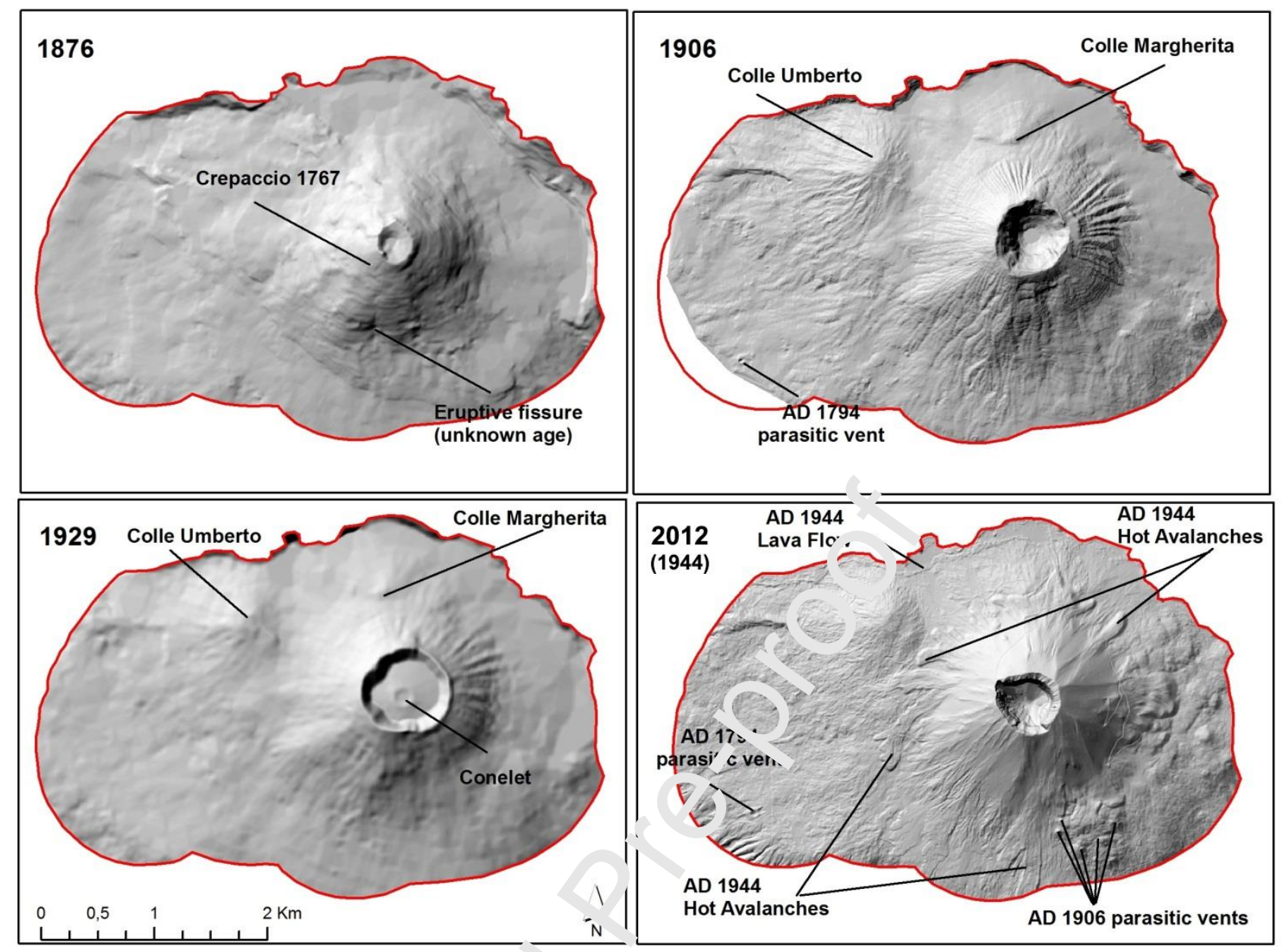

Figure 3: Shaded reliefs of SV summit calde a for the a) 1876, b) 1906 and c) 1929 years; d) shaded relief of the 1944 year obtained using ALS data 2012)

\subsection{Topography frc $\eta$, LS}

For the present-day topography, ALS data acquired during 2012 year by the Province of Naples have been processed to obtain a very high resolution $(1 \mathrm{~m})$ elevation model. The ALS or LiDAR (Light Detection and Ranging) is a remote sensing technique able to acquire millions of a surface X, $\mathrm{Y}, \mathrm{Z}$ points ("points cloud") by scanning the surface itself with an instrumental system (Infrared Sensor, IMU and GPS) mounted on an aircraft or helicopter. The source data covering the study area were elaborated and organized following the procedure described in Pizzimenti et al. (2016). The result is an accurate DEM that reproduces the actual morphology of SV caldera zone (Fig. 3d) with very high spatial resolution (cell size $1 \mathrm{~m}$ ) and planimetry and altimetry accuracy equal to \pm 30 
$\mathrm{cm}$ and $\pm 2 \mathrm{~cm}$, respectively (Pizzimenti et al., 2016). Taking into account that the volcano is quiescent from 1944 and that from this date the remarkable mass wasting/gravity-driven phenomena were recorded only in areas located outside the SV summit caldera (Bisson et al., 2017 and references therein), the DEM from ALS was considered representative of the SV caldera zone topography after the eruption of 1944. With this assumption, the morphological changes of minor entity generated by secondary erosion phenomena (e.g. wind, intensive precipitation, water runoff) are not here considered. Since these latter can be considered negligible with respect to morphological changes caused by the eruptive activity, we think that is is reasonable to include their contribution in the range of error estimated for each volume a ıu virtace calculated in this study.

\subsection{Spatial accuracy of the 3D historical topogranhies}

The accuracy of the data represents a crur ial poit for obtaining DEMs capable of reproducing topographies as realistic as possible anc' consequently to derive reliable quantitative data. For this reason, it is fundamental to provide an er ii uation of such accuracy by quantifying the errors of the source data and derived products 1 'Terefore, in order to calculate the error in $\mathrm{x}, \mathrm{y}$ and $\mathrm{z}$ of the historical topographies, the 2012 ALS DEM has been used as the reference model because it reproduces the actual to ${ }_{\mathcal{H}} \mathrm{ng}_{\mathrm{I}} \mathrm{nh}_{\mathcal{J}}$ with very high resolution and accuracy (see previous section). The spatial error in $\mathrm{x}$ and $\mathrm{y}$ of the historical maps has been calculated by using the Vesuvius Observatory as a reference, because it is an historical building well recognizable in each map. In particular, we have identified the centroid of the edifice in each historical map and compared the respective coordinates ( $\mathrm{x}$ and $\mathrm{y}$ ) with those of the centroid of the same edifice reproduced in the 2012 ALS Model (x: 449185 m; y: 4519829 m). The differences in x and y (x/y) of the centroid were calculated by subtracting the respective historical coordinates from the ALS coordinates, and is equal to $+48 \mathrm{~m} /+24 \mathrm{~m}$ (1929), $-21 \mathrm{~m} /+30 \mathrm{~m}$ (1906) and +40 m/+50 m (1876). 
To estimate the error in height of the historical topographies, we have constructed two profiles defined "calibration profiles" that analyse the elevation of each DEM in the same points. The profiles, one in N-S direction and the other in the W-E direction (Fig. 4), have been drawn to cross areas not affected by post 1876 morphological changes, according to literature data referring to the investigated time. In addition, to assure a correct analysis of the profiles, the geo-referenced historical maps were preventively co-registered to the ALS DEM by using the Vesuvius Observatory as tie point and the errors in $\mathrm{x}$ and $\mathrm{y}$ of each historical map have been also recalculated by using the RMSE reported in Table 2.

Table 2 - Errors in $\mathrm{x}$ and $\mathrm{y}$ of the historical cartography

\begin{tabular}{cccc}
\hline Historical Map & Number of $^{\circ}$ points & RMSE iı $\boldsymbol{\lambda}$ & RMSE in Y \\
\hline 1876 & 10 & -11.5 & \pm 23 \\
1906 & 10 & \pm 13 \\
1929 & 10 & \pm 19 & \pm 16 \\
\hline
\end{tabular}

The calibrations profiles $(\sqrt{ }-\mathrm{E}$ and $\mathrm{N}-\mathrm{S})$ were constructed by plotting the heights every $25 \mathrm{~m}$, a value defined according to the tolerance error of each historical map. For the height error calculation, only the points falling in areas not affected by the post-1876 deposits have been considered because they are representative of a topography that should not have changed in the last century. Therefore, despite the calibration profiles W-E and N-S (Fig. 4) plot a total of 80 and 102 points, respectively, only 84 points (32 from W-E profile and 52 from N-S profile) are used for estimating the height error of each historical topography through the calculation of the RMSE. The values of RMSE result $\pm 11 \mathrm{~m}, \pm 4.5 \mathrm{~m}$ and $\pm 11.5 \mathrm{~m}$ for the 1876,1906 and 1929 elevation topography, respectively. 

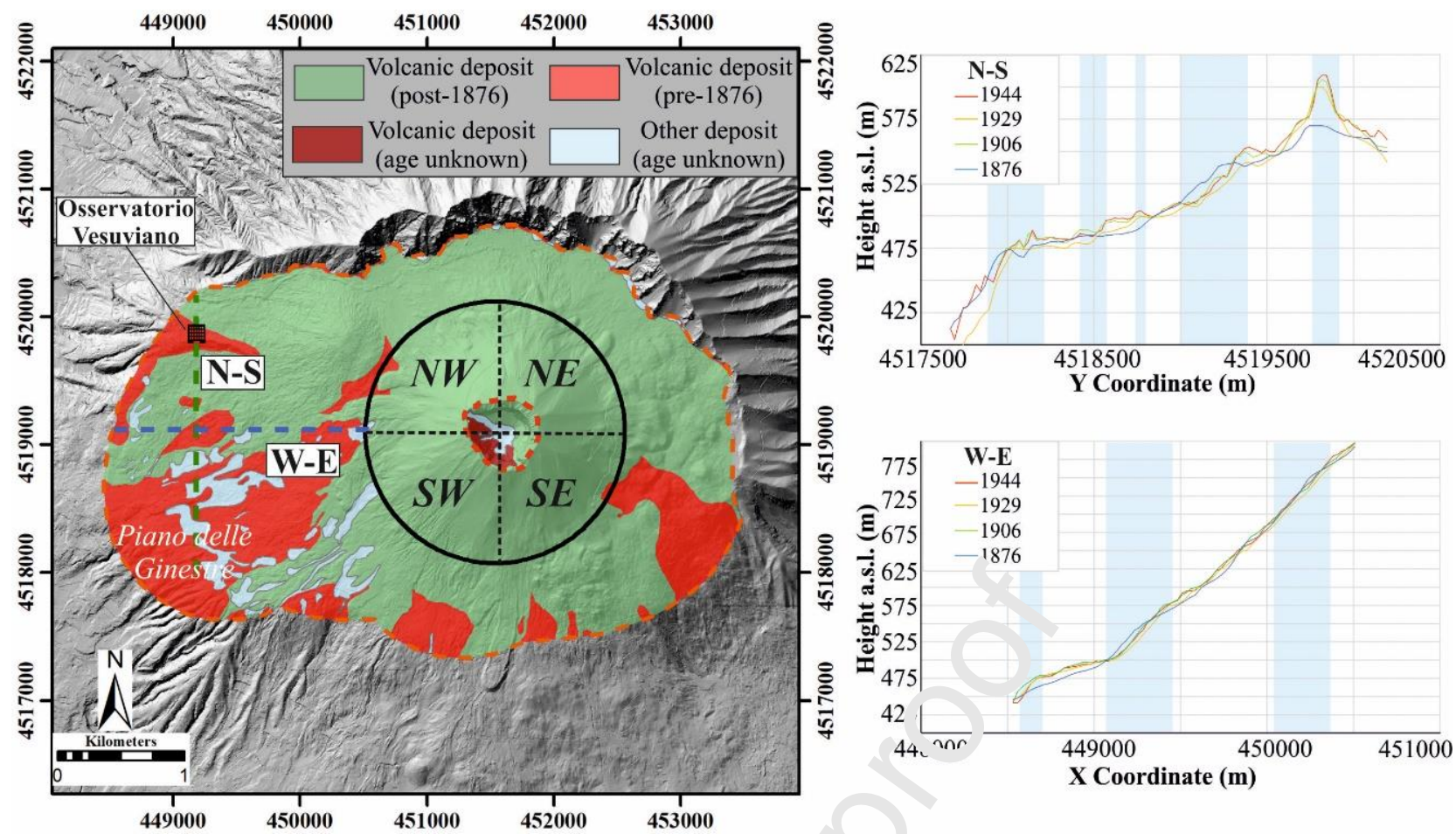

Figure 4 - The traces (left) and relative calibratior $r_{i}$ files (right). The image shows the simplified geological units from Santacroce and Sbrana (2003) sup extent of SV summit caldera is represented $b<a n_{c}$ ' dashed line, whereas the 1944 SV crater rim is outlined with a red dashed line. The "NW", VF", "SW" and "SE" abbreviations identify the four Gran Cono quadrants defined according to the cardina noints. The coordinates are in the UTM WGS84 33N system. In the graphs, the portions of the prolı' ${ }^{\circ}$ s used for the calibration are highlighted in light blue.

\section{MORPHOLOGICAL CHA'YGS OF GRAN CONO FROM 1876 TO 1944: ANALYSES} AND DISCUSSION

Since the four DEMs (Fig. 5) do not have the same extent, we have determined a common area to analyse the morphological changes during the last century. This latter corresponds to the Gran Cono area, outlined by a circle with a radius of $1 \mathrm{~km}$ (Fig. 4, 6) as defined in Tadini et al. (2017). The analyses applied to the elevation models and the obtained results are organized in three different subsections: i) identification of the most important volcanic morphologies (i.e. lava and pyroclastic deposits, avalanches, parasitic effusive vents related to past specific eruptions) through specific maps derived from the DEMs and a set of elevation profiles; ii) description of the most significant 
changes occurred in the crater area; iii) estimations in surface and volume changes of the Gran Cono edifice from 1906-1944.

\subsection{Identification of volcanic morphologies}

Despite the different accuracies of the source data, the shaded reliefs of the four DEMs (Fig. 3) show very clearly a series of morphological changes occurred in the SV caldera zone during the 1876-1944 period. The four shaded reliefs highlight: i) substant; 1 entargements and reductions of the Gran Cono crater rim through time; ii) the presence of sr me volcanic structures such as "Colle Margherita" and "Colle Umberto" since 1906 (Fig. 3b); i:) li: formation of a "conelet" (Scandone et al., 1993) inside the crater of 1929; iv) a series of pa ası: vents dated 1794 or of unknown age; v) some eruptive fractures such as "Crepaccio 175 ' "ell recognizable in the 1876 topography; vi) lava flows and "Hot Avalanche" deposits 1. 'a'ed to AD 1944 eruption and well reproduced in the ALS topography (Fig. 3d). Also the slop maps shown in Fig. 5 allow to appreciate the above mentioned morphological changes $h_{0}{ }_{0}^{h} h_{\sigma}^{-1}$ ting, in particular, the strong modifications of the Gran Cono crater. With the AD 1906 el « ntion, the extent of the crater increases, and its internal portion is characterized by very steep and i - $p$ walls. Then, with the AD 1929 eruption, the crater rim further enlarges, and the morpholı ¿y becomes gentler, since the internal walls shows moderate slopes $(<$ $\left.15^{\circ}\right)$ and the bottom results prevalently flat. Finally, with the AD 1944 eruption, the morphology changes again, the extent of the crater diminishes assuming the nowadays dimension and the internal portion presents steeper walls that remind those of the 1906 crater. 

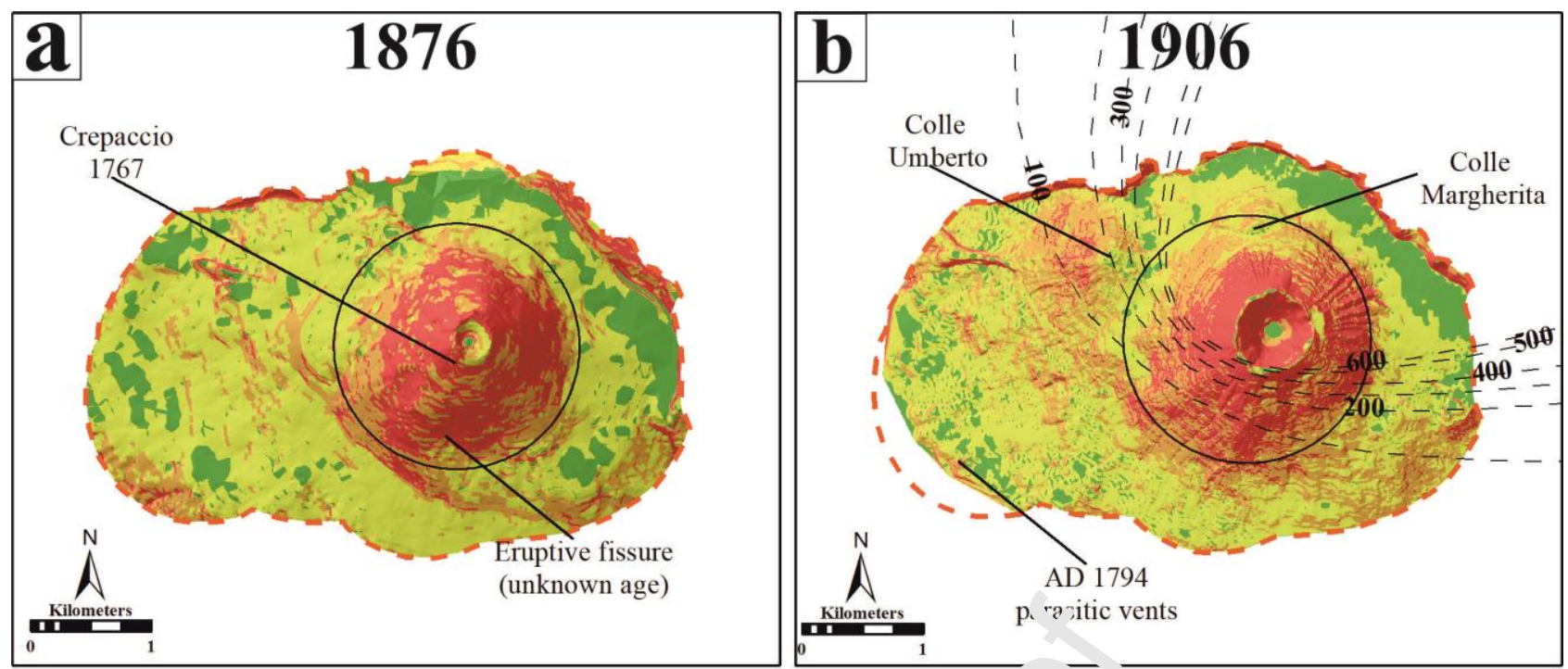

Slope classes $\left({ }^{\circ}\right)$

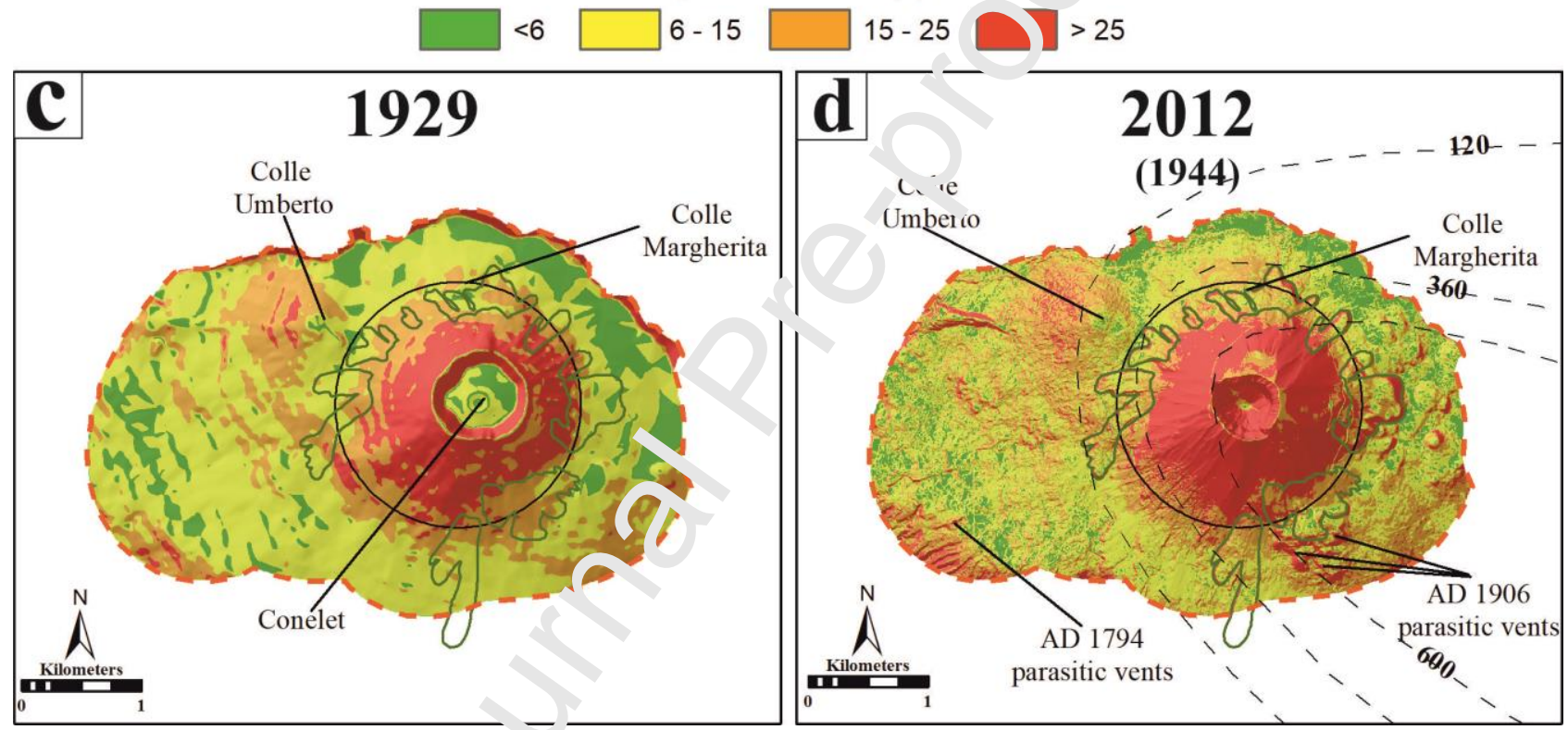

Figure 5 - Slope maps for the 1876 (a), 1906 (b), 1929 (c) and 1944 (d) DEMs. In b) the dashed black lines are loading isolines (in $\mathrm{kg} / \mathrm{m}^{2}$ ) ff the tephra fallout deposit from the AD 1906 eruption (Bisson et al., 2007). In c) and d) the solid green lines are the traces of the "Hot Avalanches" deposits of the AD 1944 eruption (modified from Santacroce and Sbrana 2003). In d) the dashed black lines represent the loads (in $\mathrm{kg} / \mathrm{m}^{2}$ ) of the tephra fallout deposits from the AD 1944 eruption (Bisson et al., 2018). The solid black circle defines the Gran Cono area.

To better analyse and quantify the morphological changes, a set of elevation profiles were derived along four main directions (N-S, W-E, NW-SE, NE-SW). In detail, for each direction, we have defined 3 traces (Fig. 6a, b) distant $500 \mathrm{~m}$ apart from each other and we have plotted the height value every $25 \mathrm{~m}$ from the 4 DEMs (1876, 1906, 1929 and 1944). In addition to the traces, Fig. $6 a$ and $b$ display the distribution of parasitic effusive vents (Tadini et al., 2017) and a simplified 
version of the geological map of Santacroce and Sbrana (2003). The elevation profiles obtained along the N-S and W-E direction are shown in Fig. 7, while those along the NW-SE and SW-NE directions are displayed in Fig. 8.

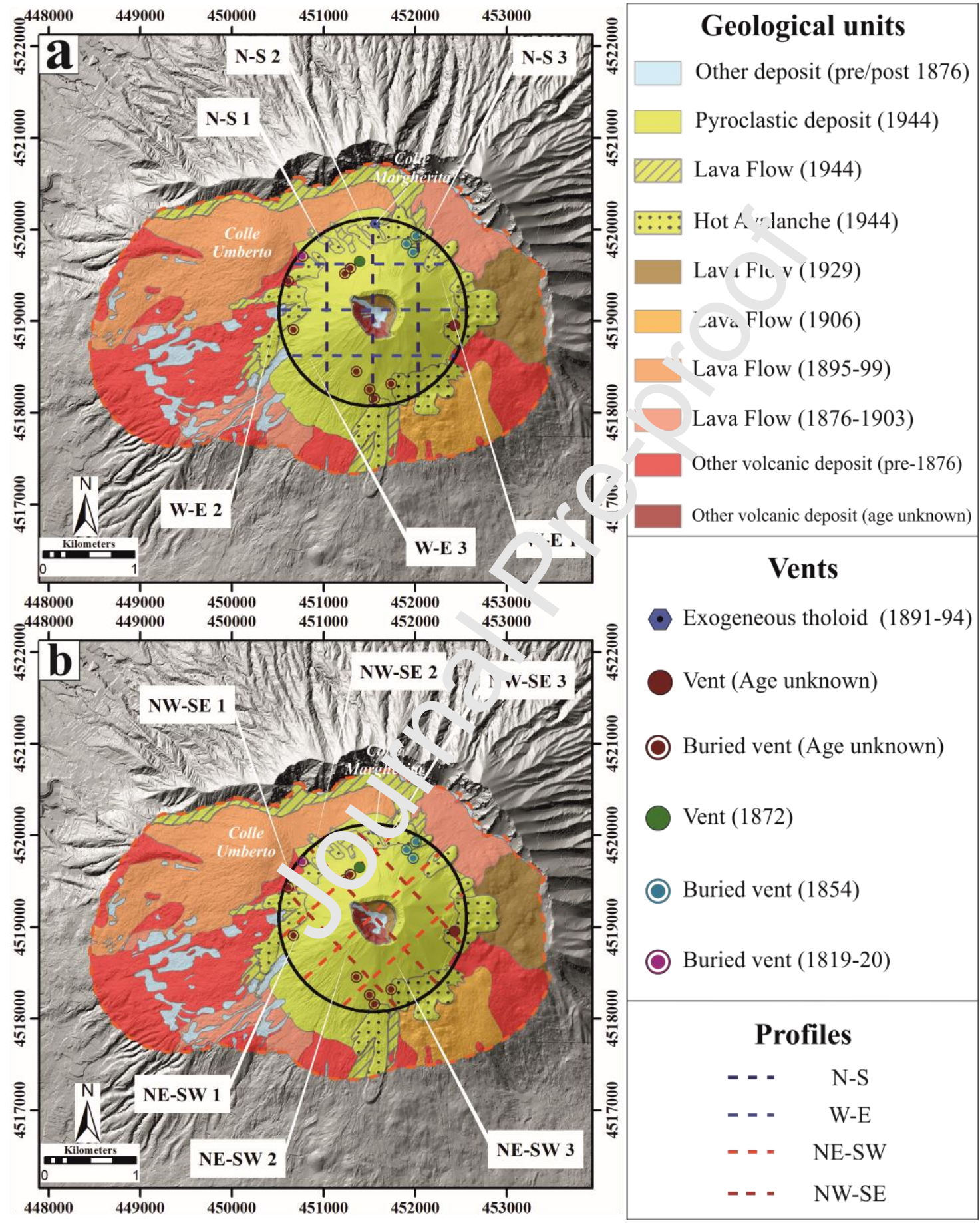

Figure 6 - Profile traces for the morphological analysis of Gran Cono area. Geological units are modified after Santacroce and Sbrana (2003). Vent positions, SV summit caldera outline (dark orange dashed line) and Gran Cono area (solid black circle with a radius of $1 \mathrm{~km}$ ) are reported after Tadini et al. (2017). In background, the shaded relief derived from 2012 ALS DEM. The coordinates are expressed in the UTM WGS84 33N cartographic system. 
With the aim of facilitating the description of the morphological changes derived from the elevation profiles (Figs. 7 and 8), we prefer to introduce the four geographic quadrants (NW, NE, SW and SE) drawn in Fig. 4 and to distinguish two zones in the Gran Cono (the "crater" zone and "flanks" zone), whose morphological changes will be discussed separately. The "crater" zone is represented by the surface bounded by the 1944 rim (red dashed line in Fig. 4) used as reference, while the "flanks" zone corresponds to the surface between the 1944 crater rim and the Gran Cono bottom (black circle in Fig. 6).

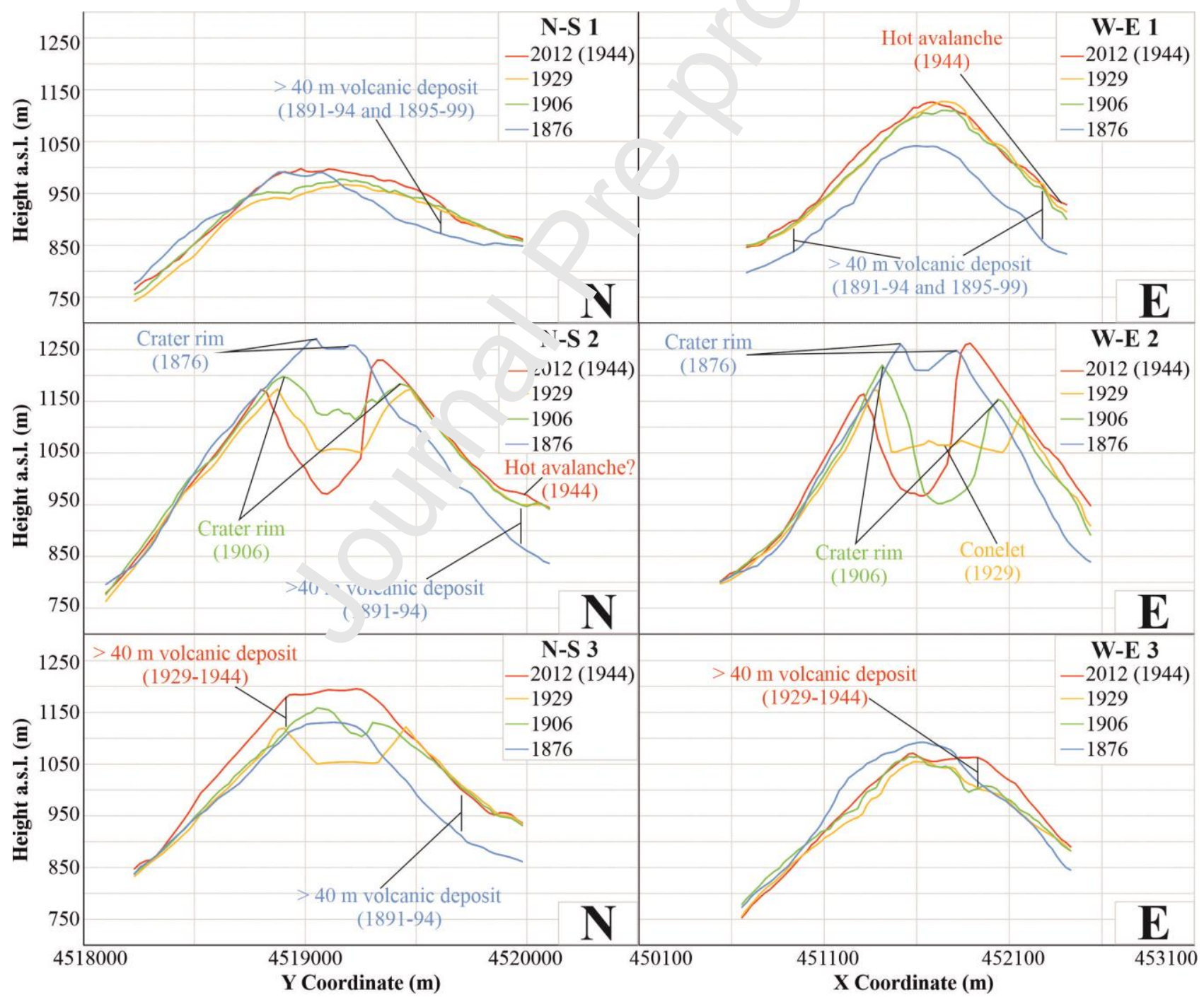

Figure 7 - N-S and W-E profiles referred to Figure 5 


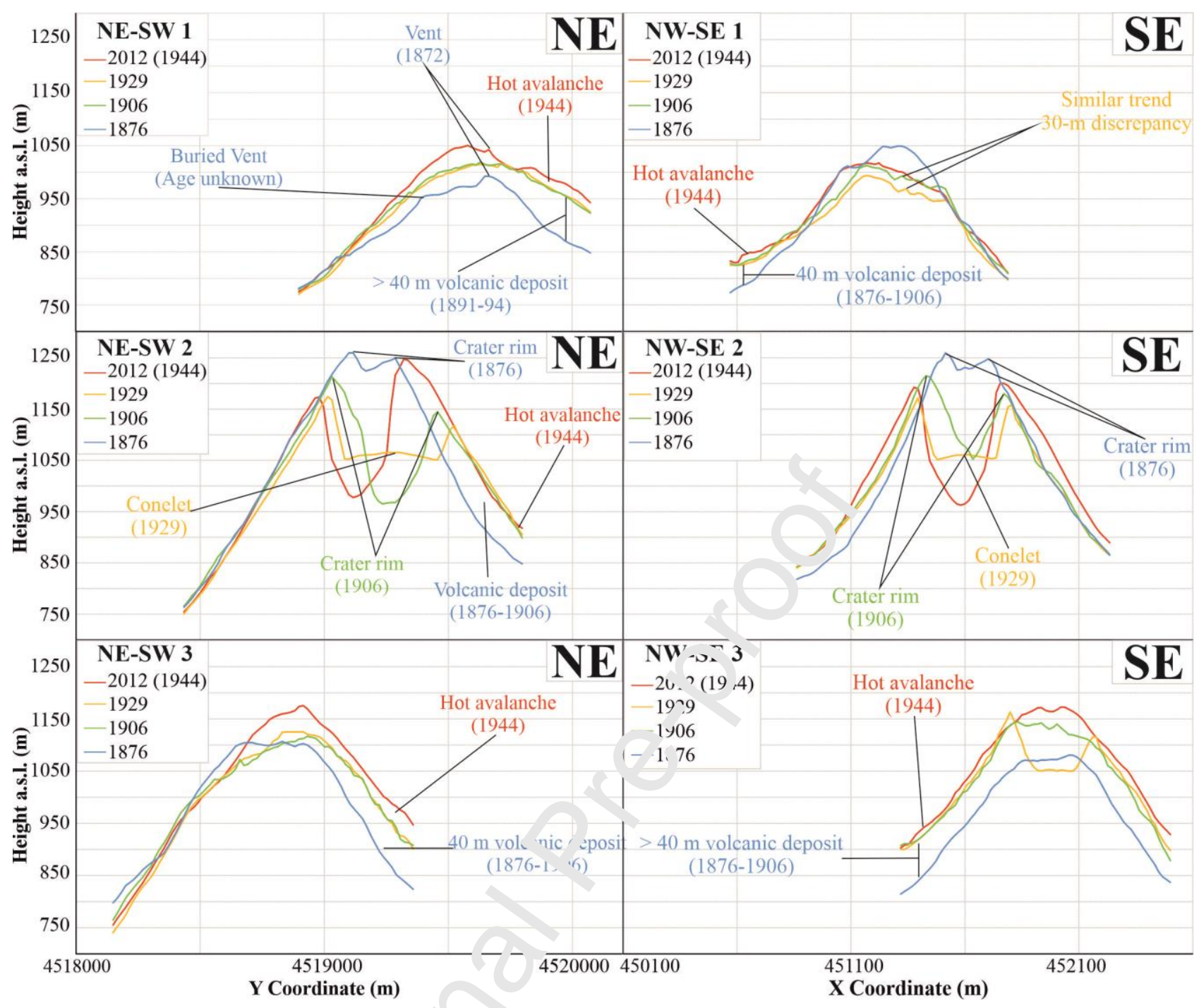

Figure 8- NE-SW and NW-SE prolı's s aferred to Figure 5.

\subsubsection{The "crater" zone}

To identify the morphological changes in the rim and bottom of the "crater" zone, we analyse the four reference profiles (W-E $2, \mathrm{~N}-\mathrm{S}_{2}$ in Fig.6; NE-SW, $\mathrm{NW}-\mathrm{SE}_{2}$ in Fig.8). The profiles show that the crater rim of 1876 , with an elevation ranging from $1250 \mathrm{~m}$ to $1270 \mathrm{~m}$ a.s.l., is clearly the highest one. All profiles indicate a gradual and progressive decrease in elevation of the crater rim from 1876 to 1929 . With the AD 1944 eruption, the $\mathrm{N}-\mathrm{S}_{2}$ and $\mathrm{NW}-\mathrm{SE}_{2}$ profiles show that the crater rim continues to decrease only in the western quadrants, whereas in the eastern quadrants it increases reaching the elevation of $1266 \mathrm{~m}$ a.s.1, very close to $1270 \mathrm{~m}$ a.s.1 of the 1876 crater (W-E 2 and NE- 
$\mathrm{SW}_{2}$ profiles). These observations suggest that the eruptions occurred from 1876 to 1929 progressively lowered the crater rim. Subsequently, the AD 1944 eruption continued to lower the crater rim only in the western quadrants, generating at the same time its remarkable growth in the eastern quadrant.

For the crater bottoms, between 1876 and 1944, the profiles show a general and progressive lowering in elevation resulting in $270 \mathrm{~m} \pm 11.5 \mathrm{~m}$ over a period of 70 years (from $1240 \mathrm{~m}$ to $970 \mathrm{~m}$ visible in the $\mathrm{N}-\mathrm{S}_{2}$ profile). In detail, with respect to 1876 , the 1906 crater bottom decreases in elevation with different values according to the analysed profile. In 1 ct, this decrease ranges from a minimum of $75 \pm 16 \mathrm{~m}$ (see $\mathrm{N}-\mathrm{S}_{2}$ section) to a maximum of $750 \cdot 270 \pm 16 \mathrm{~m}\left(\mathrm{~W}-\mathrm{E}_{2}\right.$ and NE-SW sections). After the 1929 eruption, the crater bottom f $\mathbf{r t h} \mathrm{r}$ decreases of $70 \pm 27 \mathrm{~m}$ in the N-S section, whereas it increases of $70-100 \pm 27 \mathrm{~m}$ in th - other sections (see NE-SW $\mathrm{SW}_{2}$ and $\mathrm{W}-\mathrm{E}_{2}$ ). With the AD 1944 eruption, all sections show that the rater bottom again decreases of $70 \mathrm{~m}$ reaching an elevation of $970 \mathrm{~m}$ a.s.l., a value that coulc have been already reached during one of the two previous eruptions (see 1906 and 1929 p.hthizs). For completeness, we also report the value of the lowest point of the crater bottom derive from the ALS DEM and resulting equal to $954 \mathrm{~m}$. a.s.l. This point is located around 25 me zrs to the south of $\mathrm{W}-\mathrm{E}_{2}$ trace (see Fig. 6a) and its elevation results very close to the $\mathrm{v}$ alut of $953 \pm 5 \mathrm{~m}$ measured by Imbò (1949) in June 1949. All these observations suggest that: 1 starting from 1876, the subsequent eruption of 1906 has strongly lowered the bottom of the crater indicating a strong eruptive activity; ii) the 1929 eruption has filled the bottom with products generated by a low magnitude explosive eruption that could be represented by an intra-caldera activity capable of forming a small conelet inside the caldera itself. These two hypotheses agree with Bertagnini et al. (1991) and Scandone et al. (2008), respectively. 


\subsubsection{The "flank " zone}

Most of the profiles (Fig. 7 and 8) show that the older topographies are lower than the subsequent ones, indicating that the flanks of the volcano, from 1876 to 1944 , progressively grow due to the accumulation of the erupted products along the flanks themselves. Only four profiles $\left(\mathrm{N}-\mathrm{S}_{1}, \mathrm{~W}-\mathrm{E}_{3}\right.$ in Fig.7; NW-SE 1 , NE-SW 3 in Fig.8) show areas where the oldest topography (1876) is the highest one. Such areas have been individuated in some portions of the SSE and SSW flanks, particularly between the crater rim and the hot avalanche deposits (Fig. 6). A cording to the errors in elevation previously calculated (see section 3.2), in such areas the real ele ation of the 1876 topography results 15 - $20 \mathrm{~m}$ lower than the one shown by the profi 's. 'articularly, during the AD 1906 eruption, such areas were affected by detachment phen smt a and erosion processes that removed material and lowered the pre-existing topography sur.ace as inferred from the profiles. Excluding such specific areas, the 1906 profiles show that . he tlanks of the 1876 volcano have been covered by the products erupted by the subsequent $v^{\prime}{ }^{1}$ canic activity (from 16/12/1881 to 22/04/1906, see Table 1). Such products reach significr a thizknesses (> $40 \mathrm{~m})$ in the NW, NE and SE quadrants, whereas in the SW quadrant their th ckı'sses are negligible in the SSW portion (as the values result equal or slightly greater than thi es vation error), and around $10-15 \mathrm{~m}$ in the WSW portion. In detail, the $40 \mathrm{~m}$ of differ $\mathrm{na}$ shown in N-S and W-E profiles (Fig. 7) could be reasonably correlated with the product erupted during the 1891-94 and 1895-99 events, whose deposits formed, respectively, the "Colle Margherita" and "Colle Umberto" morphologies (see Figs. 3b and 6 and also Scandone et al. 2008). In particular, the "Colle Margherita" edifice, now partially buried by the subsequent products, might be identified in the North part of the $\mathrm{N}-\mathrm{S}_{2}$ profile (Fig. 7).

The comparisons between the 1906 and 1929 profiles highlight very similar topographies. This suggests that the AD 1929 eruption did not produce significant deposits on the flanks and that the 25-30 m discrepancy, highlighted in the central portion of the NW-SE 1 profile (Fig. 8) and reduced to around $10 \mathrm{~m}$ considering the elevation errors (Table 2), is probably not real. This hypothesis 
seems to be supported also by the fact that the discrepancy remains constant along the entire central portion of the profile. In our opinion, such discrepancy of 10 meters could be explained considering that the central portion of $\mathrm{NW}-\mathrm{SE}_{1}$ profile crosses a particular area of the SW quadrant where the historical maps draw the zone affected by the eruptive fissure named "Crepaccio 1767" (visible in Fig. 3a) with morphologies poorly resolved and therefore difficult to draw during the digitalization. For this reason, it is possible that some contour lines of the older map (1906), characterized by a more detailed scale $(1: 10,000)$, have been directly copied to the younger one (1929) acquiring the altimetry error of the younger map (Fig. 2, Table 2) that is nrutuced at less detailed scale $(1: 25,000)$. These issues are often common when working wi ${ }^{\circ}$ is istorical maps, and should be taken into account to derive the most accurate descriptions from nrofile analysis. Also the comparison between the 1944 topography and the antecedent 1929 on shows significant differences in height (> $40 \mathrm{~m}$ ) in the $\mathrm{N}-\mathrm{S}_{3}$ and $\mathrm{W}-\mathrm{E}_{3}$ profiles (Fi؟. - ) In addition, most of the profiles identify morphologies clearly correlated to peculic* $d$-posits generated from the AD 1944 eruption and named "Hot avalanche" (Santacroce and ¿hrana 2003; Cole and Scarpati 2010 - see also Fig. 3d). These deposits are well recognizable in t.e $\mathrm{N}-\mathrm{S}_{2}, \mathrm{~N}-\mathrm{S}_{3}, \mathrm{NW}-\mathrm{SE}_{1}$ and $\mathrm{NW}-\mathrm{SE}_{3}$ and are in agreement with the maps of Figs. 3d and 5, where the deposits cover several portions of the volcano flanks mainly involving the NW, NL ar.d SE quadrants. As described by Hazlett et al. (1991), such peculiar type of debris ava' 'nuiles, triggered by a seismic crisis, took place near the end of the main eruptive phase (although long before the end of the eruption) and removed $\sim 5-10 \times 10^{6} \mathrm{~m}^{3}$ of material from elevations $>900 \mathrm{~m}$ a.s.l. in the Gran Cono area. The "Hot avalanche" deposits in the profiles reach thicknesses of 20 - $25 \mathrm{~m}$, consistent with those reported in Hazlett et al. (1991). The last observations inferred from the profiles are related to some particular morphologies named "parasitic effusive vents". Such morphologies, well recognizable also on the shaded relief derived topographies (Fig. 3), are visible in the NE-SW 1 profile referred to 1876 topography (Fig. 8). In fact, such profile is characterized by a sequence of concave/convex shapes that could indicate the presence of some parasitic effusive vents located in the NW quadrant (see Fig. 6). In particular, the 
convex shape to the NE might be correlated with the 1872 vent, whereas the other shapes can be correlated with the two buried vents visible along the NE-SW 1 trace of Figure 5. In addition, the 1872 vent can be also identified in the 1944 NE-SW 1 profile by a peculiar angular shape located in the same position assumed by the vent itself in the 1876 profile. Such vent is identified also in the 1944 shaded relief map (Fig. 3d).

In order to improve the discussion about the "Hot avalanche" deposits and to provide some quantitative measurements on the volumetric changes along the Gran Cono flanks, we have analysed the slope maps (Figure 5) overlaying the boundaries c the "Hot avalanche" deposits and the loading isolines $\left(\mathrm{kg} / \mathrm{m}^{2}\right)$ of the tephra fallout deposits ( $f$ th: AD 1944 eruption. Despite the different degree of resolution of the maps, Figure 5 allc vs further observations beyond those already discussed in the section 4.1. In detail, the $s^{1} \sim n e$ maps help to better constrain the limits of the AD 1944 "Hot avalanche" deposits. In nat ‘ular, Figure 8c and 8d, highlight that for such deposits, in agreement with what observed by Yazlett et al. (1991), i) their source areas are located in zones characterized by slopes $>\varkappa^{\circ}$ a.id that ii) their accumulation areas are located in correspondence of areas with slores anging between $6^{\circ}$ and $15^{\circ}$, recognized in literature as thresholds values for the deposivin phase (Bisson et al. 2007 and reference therein). In addition, Figures $8 \mathrm{c}$ and $8 \mathrm{~d}$ highlight tha such deposits are not present in the SW flank suggesting that their occurrence could depend or the sector of the volcano. The "sector-dependency" hypothesis has been already formulated by Hazlett et al. (1991), who explained that the AD 1944 hot avalanches developed along slopes characterized by at least one of the following elements: i) being preloaded with AD 1944 lava flows (for the N, S and W deposits, see also Fig. 6) or ii) having had high accumulation of tephra deposits from both the AD 1906 and AD 1944 eruptions (for the E deposits, see loading lines of both AD 1906 and AD 1944 eruptions in Fig. 5). None of these two elements characterize the SW flank of Gran Cono. 
The visualization of the above-mentioned main topography changes can be better appreciated through the 3D perspective views of the Gran Cono performed at different time frames and shown in Figure 9. The 3D views allow to present the main steps of the morphological evolution of the Gran Cono. Firstly, we observe a crater area (rim and bottom) prevalently dismantled at least until the 1929 eruption (Fig. 9a,b). With the AD 1944 eruption, the trend changes only for the eastern crater portion that, with a remarkable re-growth, reaches elevations close to those of the 1876 crater rim (Fig. 9c). Moreover, if we consider the entire investigated period (1876 - 1944) as a whole (Fig. 9d), it is possible to observe how the South flank of the Gran Conc, after the AD 1944 eruption, does not reach the elevations of the 1876 oldest topography. ' $v \mathrm{st}^{\prime}$ respect to the flanks, it is evident a progressive growth that involves the NW, NE, and SF su tors. These observations are in good agreement with the fact that the crater areas of the volcan as are generally characterized by cycles of erosion and growth in elevation, whereas th: "an's are generally affected by an increase in elevation due the deposition and accumula 'n of products emitted during an eruption, such as, for example, lava flows and fall out deposits.
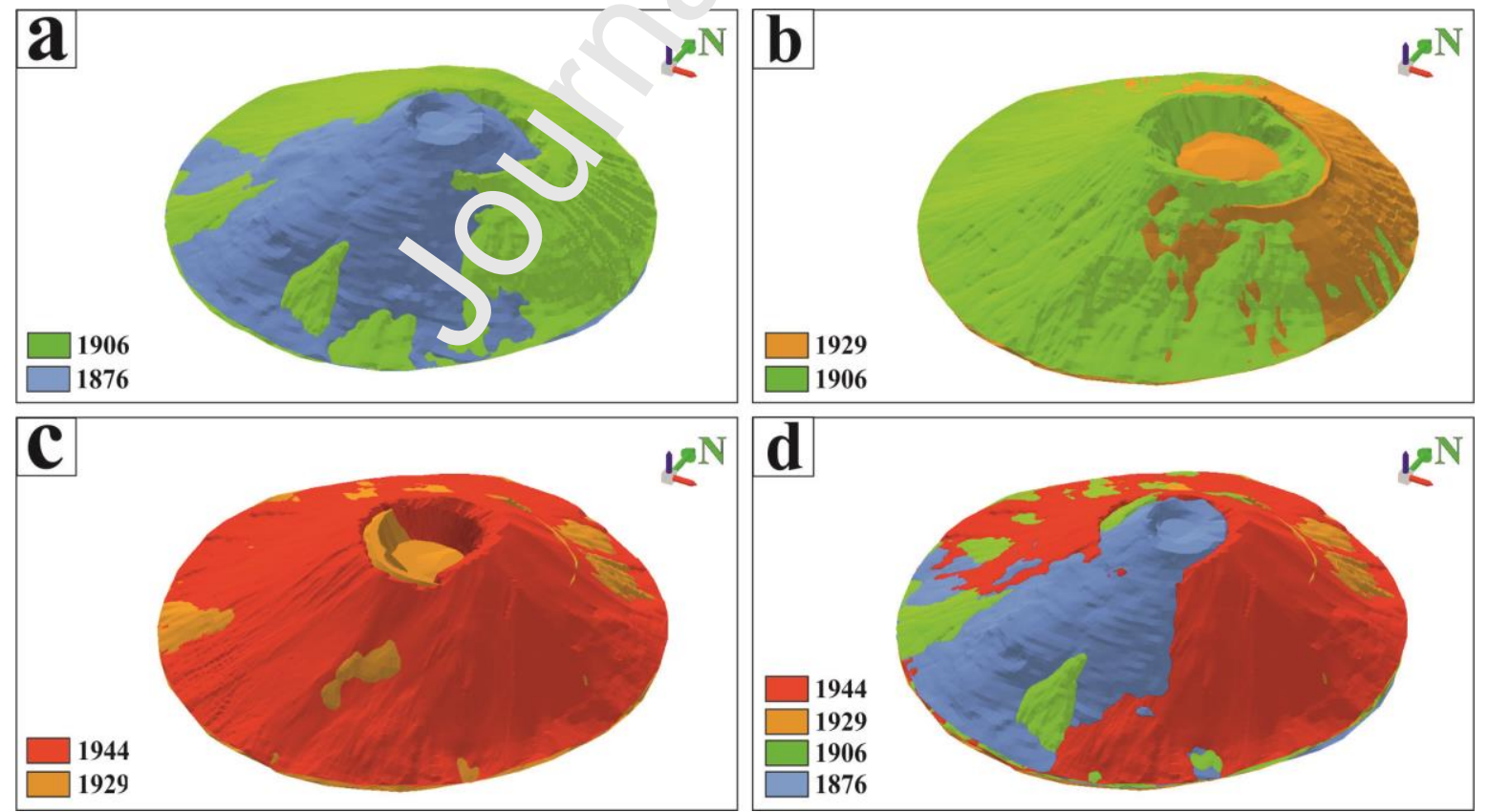

Figure 9-3D perspective views of the morphological changes for different time frames: a) 1876-1906; b) 1906-1929; c) 1929-1944; d) the whole investigated period (1876 - 1944). 


\subsection{Crater rims comparison}

The morphological changes of the crater area through time were investigated not only through the elevation profiles (Figs. 6 and 7) but also by analysing some specific geometric parameters of the crater area itself (see Table 3). These elements were obtained after the digitalization of the four crater rims and the representation of their geometric centroids (Fig. 10). Figure 10 shows significant changes in the extent of the crater rim that mainly involve the E and N-E areas of the Gran Cono summit portion. In addition, Figure 10 highlights an alignment c $\{$ the centroids along the NE-SW direction suggesting possible displacements of the eruptive centr along such direction. These displacements, quantified with the parameters reported in 1 ?ble 3 , are calculated considering the errors in $\mathrm{x}$ and y previously defined (Table 2). The resu is s ow a real migration of at least $50 \mathrm{~m}$ of the crater centroid towards NE from 1876 to $1929, \rho^{n-1}$ of at least 170 m towards SW between 1929 and 1944. Moreover, it is evident a substantial e $^{1}{ }^{1}$ argement of the crater rim from 1876 to 1929 , in fact its extent remarkably increases from $0 . \mathrm{c}^{\mathrm{k}} \mathrm{km}^{2}$ to $0.46 \mathrm{~km}^{2}$. Subsequently, with the AD 1944 eruption, the crater rim significantly red $\mu$ as is extent, reaching the current area of $\sim 0.25 \mathrm{~km}^{2}$.

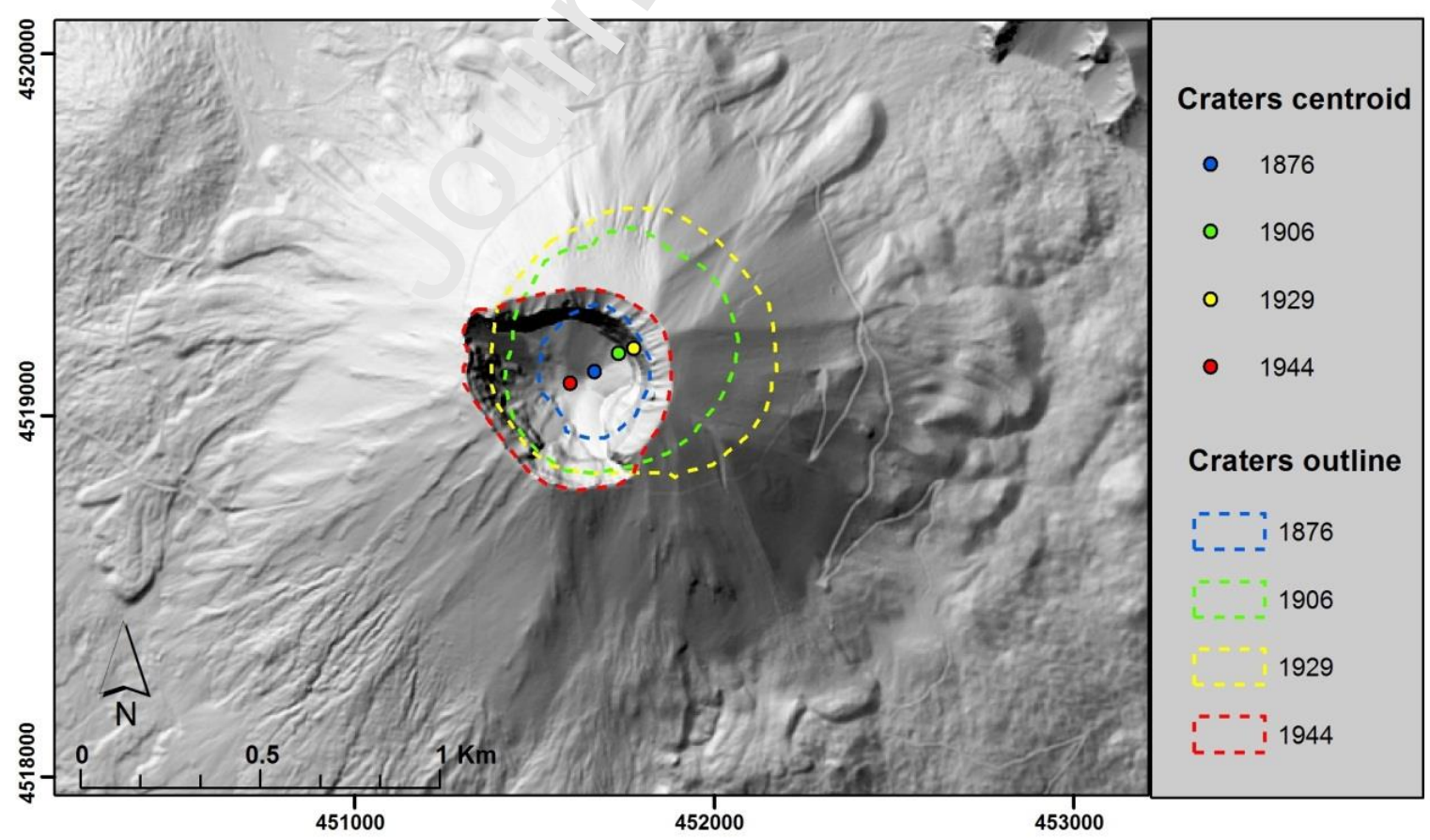

Figure 10 - Crater rim traces $(1876,1906,1929,1944)$ 
Table 3: Gran Cono crater rim parameters calculated in different time.

\begin{tabular}{|ccccccc|}
\hline Year & $\begin{array}{c}\text { Crater } \\
\text { centroid X } \\
\text { coordinate } \\
(\mathbf{m})\end{array}$ & $\begin{array}{c}\text { Crater } \\
\text { centroid Y } \\
\text { coordinate } \\
(\mathbf{m})\end{array}$ & $\begin{array}{c}\text { Crater } \\
\text { Extent } \\
\left(\mathbf{m}^{\mathbf{2}}\right)\end{array}$ & $\begin{array}{c}\text { Crater centroid } \\
\text { distance from the } \\
\mathbf{1 9 4 4} \text { one } \\
(\mathbf{m})\end{array}$ & $\begin{array}{c}\text { Crater centroid } \\
\text { distance from } \\
\text { previous one } \\
(\mathbf{m})\end{array}$ & $\begin{array}{c}\text { Crater centroid } \\
\text { migration } \\
\text { direction from } \\
\text { previous one }\end{array}$ \\
\hline $\mathbf{1 8 7 6}$ & $451667 \pm 18$ & $4519121 \pm 23$ & 85345 & $\mathbf{7 5 \pm 2 3}$ & - & NE \\
$\mathbf{1 9 0 6}$ & $451732 \pm 15$ & $4519172 \pm 13$ & 329651 & $\mathbf{1 5 6} \pm \mathbf{2 0}$ & $61(35-130)$ & NE \\
$\mathbf{1 9 2 9}$ & $451774 \pm 19$ & $4519186 \pm 16$ & 463629 & $\mathbf{2 0 0 \pm 2 7}$ & $45(16-92)$ & SW \\
$\mathbf{1 9 4 4}$ & 451599 & 4519088 & 248729 & - & $200(173-227)$ & \\
\hline
\end{tabular}

The values in brackets indicate the minimum and maximum distance a ' ording to the $\mathrm{x}$ and $\mathrm{y}$ errors of the respective maps.

By analysing more in detail the spatial position of the cr tte $_{\imath}$ sentroid during the investigated period, we can observe a progressive migration of the centrniı towards NE from 1876 to 1929, and then, during the 1929-1944 period, towards the $S^{1 / T}$ ( $\mathrm{rg}$. 10). This latter migration seems to be contemporaneous to the strong increase in ht: ht of crater rim in the NE quadrant (see section 4.1), whereas the first migration is concomits $-\mathrm{t} w$ : th a progressive lowering of the crater rim in the NW and SW quadrants. The distances 'se 'reen the centroids of all crater rims have been estimated considering the errors in $\mathrm{x}$ and $\mathrm{y}^{\prime} \mathrm{c}^{1}$ culated after the co-registration procedure (Table 2 in section 3.3). This preferential directivi or centroid migration (NE-SW) is parallel to the strike of one of the two main deep fault systems below SV (Bianco et al., 1998; Tadini et al., 2017; Tramparulo et al., 2018). In detail, the 1876 crater rim covers an area of $0.08 \mathrm{~km}^{2}$ and its centroid is positioned at a distance of $75 \pm 23 \mathrm{~m}$ in NE direction with respect to 1944 centroid (see Fig. 10). With the AD 1906 eruption, the crater rim enlarges defining an area of $\sim 0.33 \mathrm{~km}^{2}$, lowers in height reaching the maximum elevation of $\sim 1220 \mathrm{~m}$ a.s.l. (Figs. 6 and 7) and migrates to the NE of at least $35 \mathrm{~m}$. With the 1929 eruption, the crater rim enlarges even more $\left(\sim 0.46 \mathrm{~km}^{2}\right)$ and its centroid migrates again towards NE of at least $\sim 16 \mathrm{~m}$ (Table 3). Although the period 1906-1929 is not characterized by major eruptions (see Table 1 and Scandone et al. 2008), the intra-crater activity does not stop. In fact, as described in Scandone et al. (1993), in this period the crater bottom is affected by two 
collapses (in the years 1911 and 1913) and lava fillings, particularly in the years 1917, 1919 and 1920. These activities have probably generated the enlargement and a lowering of the crater rim that reaches an elevation not exceeding $1176 \mathrm{~m}$ a.s.l. (Fig. 6). This value is probably already reached by the 1920 crater rim as showed in the inset of Fig. 2c. This indicates that the intra-crater activity of the period 1920-1929 (see Scandone et al. 1993 for details) and, in particular, the AD 1929 eruption (Table 1 and Scandone et al. 2008) does not cause collapses on the crater rim, but, on the contrary, they contribute to reconstruct the Gran Cono original outline. Finally, the present day crater, generated by the AD 1944 eruption, shows a centroid migrated of at least $170 \mathrm{~m}$ towards SW aligned with the other centroids. The 1944 crater rim, co eing an area of $\sim 0.25 \mathrm{~km}^{2}$, results particularly reduced with respect to the previous one $(\sim 5(),-)$ and, in a portion of the NE edge, is very similar to the 1876 rim (Figs. 6 and 10). This ren'iction could suggest accumulations of material which, at least in part, may have occu $r$ r retween 1929 and 1944. This hypothesis is supported by Cole and Scarpati (2010) and 'ca .done et al. (1993). In fact, Cole and Scarpati (2010) confirm that, prior to the AD 1944 erupi $>n$, the crater was nearly completely filled with a small conelet in the middle area and Scandnne of al. (1993) points out that in the period 1929-1944 many lavas $(1930,1935,1936,1937,1 \cdot 39,1940,1942)$ outflows from the crater toward N, NE and E. These outflows, at least in parı, cuuld explain the growth of the Gran Cono in the NE quadrant, where the crater rim reachs values higher than $1250 \mathrm{~m}$ a.s.l. (see W-E $\mathrm{E}_{2}$ and NE-SW 2 profile in Fig. 6 and Fig. 7, respectively). Also Cole and Scarpati (2010) support such interpretation pointing out that during all the phases of the AD 1944 eruption, most of the pyroclastic products have accumulated in the NE and SE quadrant of the Gran Cono edifice. After the emptying of most of the intra-crater material, the AD 1944 eruption carved the present shape of the Gran Cono, whose crater, in our model, reaches the highest elevation (1277 m a.s.l.) in the NE quadrant. This value is in good agreement with the measurements of Imbò (1949). 
4.3 Volume and surface changes estimations

Estimates of volume and surface change of the Gran Cono edifice were made by processing the altimetry models with the specific matrix operators available on the GIS platform. In detail, we calculated the volumes by using altimetry models stored in ESRI - GRID format with a spatial resolution of $5 \mathrm{~m}$ and the surface from the ESRI - TIN vector format. The calculations were performed starting from a plane coincident with the circle having radius of $1 \mathrm{~km}$ (see Fig. 4). Table 4 reports the values of the surface and volume of the Gran Conc edifice for each altimetry model highlighting a general increase both in volume and in surface fro n 1:76 to 1944 .

Table 4 - Volumes and 3D Surfaces of the Gran Cono through t: '

\begin{tabular}{|c|c|c|c|}
\hline Year & $\begin{array}{l}\text { Gran Cono } \\
\text { volume }\left(\mathbf{m}^{3}\right)\end{array}$ & $\begin{array}{l}\text { Volumet ic } \\
\text { change ir } n \\
\text { pro vie is }\left(\eta^{3}\right)\end{array}$ & $\begin{array}{l}\text { Gran Cono } \\
\text { surface }\left(\mathrm{m}^{2}\right)\end{array}$ \\
\hline 1944 & $824.1 \times 10^{6}$ & $+51.4 \times .7^{6}( \pm 5 \%)$ & 3871135 \\
\hline 1929 & $772.7 \times 10^{6}( \pm 4.9 \%)$ & $77<10^{6}( \pm 7 \%)$ & $3751222 \pm 3800$ \\
\hline 1906 & $745.7 \times 10^{6}( \pm 2 \%)$ & $\left\llcorner 54.2 \times 10^{6}( \pm 7 \%)\right.$ & $3835957 \pm 2420$ \\
\hline 1876 & $691.5 \times 10^{6}(2<2 \%)$ & - & $3725202 \pm 3670$ \\
\hline
\end{tabular}

The error in $\%$ of each volume 'in brackets) was calculated considering the errors in height reported in the section 3.2 .

This trend is coherent with the fact that the 1876 - 1944 period was overall characterized by an intense volcanic activity (Scandone et al., 2008) resulting in a total volume increase of the Gran Cono equal to $\sim 133 \times 10^{6} \mathrm{~m}^{3}$ (Table 4). Most of this increase in volume is achieved during the 18761906 and 1929 -1944 volcanic activities. During the 1876-1906 period, the volume of Gran Cono increases of $\sim 54 \times 10^{6} \mathrm{~m}^{3}$ (Table 4) including two main events such as the building of "Colle Margherita" (1891- 94; Table 2) and the AD 1906 eruption. In general, the products of the AD 1906 eruption correspond to deposits with thicknesses of 30 - $40 \mathrm{~m}$ well recognizable in several profiles 
of the Figs. 6 and 7 and consist of lava flows and proximal tephra. With the aim to calculate the volume of the proximal tephra along the Gran Cono flanks, we have superimposed the loading isolines of the AD 1906 tephra fallout deposits (Fig. 5b), individuated those that involve the Gran Cono area and worked only on the portions comprised between the identified loading lines. For each portion, the mass was calculated by multiplying the area for the mean value between the two involved loading lines. Then, the sum of all masses was transformed in volume considering a deposit density value equal to $1100 \mathrm{~kg} / \mathrm{m}^{3}$ (Barsotti et al., 2015). The resulting volume for the AD 1906 tephra fallout deposits along the Gran Cono is $1.13 \times 10^{6} \mathrm{~m}^{3}$ Thi value accounts for $\sim 2.0 \%$ of the volume increase between 1876 and 1906 (Table 4) and $\sim 1.5 \%$ of the total tephra deposit volume of the AD 1906 (April) eruption (Table 2).

The second relevant volumetric increase is referred +n the 1929-1944 period and corresponds to $51 \times 10^{6} \mathrm{~m}^{3}$ of erupted material and accumulated, 7 the Gran Cono area (Table 4). During this time frame, the most important eruption is the AL 1944 one (Table 2), which produced lava flows, hot avalanches and tephra fall out deposits ${ }^{r}$ rouably, part of the tephra was emplaced on the flanks of the edifice, causing a certain growth in 1 ight of the Gran Cono structure (see profiles in Figs. 7 and 8). By using the same procedu ${ }^{\circ}$ prformed for the AD 1906 eruption, we have calculated the volume of tephra fallout de pos'ts of the AD 1944 eruption along the Gran Cono (Figure 8d). The resulting value is $1.25 \times 10^{6} \mathrm{n}^{3}$ and corresponds to $\sim 2.4 \%$ of the volumetric increase reported in Table 4 and $\sim 1.9 \%$ of the total tephra of the AD 1944 eruption (Table 2).

Also the surface of the Gran Cono (Table 3) shows an increase of $\sim 0.14 \mathrm{~km}^{2}$ from 1876 to 1944 , although being not progressive through time. In detail, the first increase (from 1876 to 1906) is equal to $\sim 0.11 \mathrm{~km}^{2}$ and can be explained considering: i) the large and thick mantling of the Gran Cono flanks generated by the accumulation of the 1906 erupted deposits and ii) the contemporaneous remarkable enlargement of the related crater rim, whose extent is four times greater than the previous one $\left(0.32 \mathrm{~km}^{2}\right.$ vs. $0.08 \mathrm{~km}^{2}$, see Table 3). Subsequently, with the 1929 
eruption, the surface decreases of $\sim 0.08 \mathrm{~km}^{2}$ despite the further enlargement of the crater rim. This decrease can be explained considering that the strong morphological changes occurred between 1906 and 1929 are mainly due to an intra-crater activity (Scandone et al., 2008) that has filled the conduit previously emptied by the AD 1906 eruption (Bertagnini et al., 1991) raising the crater bottom at higher elevations. This feature, coupled with the lowering of the crater rim elevation of the 1929 profiles (see Fig. 6 and 7), contributed to decrease the extent of the surface of the inner part of the crater. A further reason of such decrease in surface could be partially due to the different scales of the original maps. In fact, the contour lines every $25 \mathrm{~m}$ ot he 1929 map creates a much less detailed morphology with respect to the 1906 one (gener cec with contour lines every $5 \mathrm{~m}$ ) and, consequently, a lower value of the calculated surface. Fin. 11 , with the AD 1944 eruption, the surface of the crater further increases reaching the great zsı value of $\sim 3.87 \mathrm{~km}^{2}$ corresponding to the nowadays surface. This value is linked to: i) the $n_{\text {. }}$ la ement of lava flows, tephra fall out and hot avalanches related to the eruption itself; ii) the increase of the crater rim elevation; iii) the remarkable lowering of the crater botton. that, consequently, increased the surface of the inner portions of the crater; iv) the very high $\mathrm{re}$ s iution of the 1944 topography that allows to quantify the area of many morphological detai' not representable in the other topographies.

\section{CONCLUSIONS}

This work presents a study on the main morphological changes of Somma - Vesuvio (SV) caldera from 1876 to 1944 based on a multi-temporal analysis of the volcano topography. For the first time, three DEMs coming from historical cartography and a DEM derived by ALS technology are compared and analysed providing a quantification of the volcano morphological changes associated to an error estimation, fundamental element to understand the accuracy/reliability degree of the obtained results. Because our results are very consistent with the available literature data, this study testifies that historical topographies of volcanic areas, if elaborated with rigorous criteria, allow to 
derive reliable quantitative and qualitative data very useful to improve the knowledge of the volcano in the past.

Four 3D topography models of Somma Vesuvio summit caldera were here reconstructed focusing then the attention on a specific zone represented by the Gran Cono edifice. The four models reproduce the SV summit caldera topography of 1876, 1906, 1929 and 2012 year. The first three models derive from the IGM historical maps, whereas the fourth model derives from the ALS data acquired on 2012 and it was assumed to be representative of the volcano topography immediately after the 1944 eruption. The four models, produced and an lyst 1 on GIS platform at spatial resolution of $5 \mathrm{~m}$, were firstly elaborated to obtain tw $\mathrm{m}$ aps (shaded reliefs and slopes) highlighting how the morphological changes on the Gri n C no involve not only the "flanks" zone with the accumulation of several volcanic deposits (mostly lava flows and pyroclastic deposits), but also the "crater" zone that significantly chanses " $\eta$ shape and dimension. The results indicate that from 1876 to 1944 the Gran Cono edifice gro "s in volume of $133 \times 10^{6} \mathrm{~m}^{3}( \pm 5 \%)$ and in surface of $\sim 0.14 \mathrm{~km}^{2}$. The volume growth is main' ${ }_{\mathrm{y}}$ duc to the AD 1906 and AD 1944 eruptions that generate, respectively, an increase of $54.2 \times 1)^{0} \mathrm{~L}^{\circ}( \pm 7 \%)$ and $51.4 \times 10^{6} \mathrm{~m}^{3}( \pm 5 \%)$, whereas with the 1929 eruption the growth is around $2 \% \cdot 1 \iota^{6} \mathrm{~m}^{3}( \pm 7 \%)$ corresponding only to the $20 \%$ of the total growth. Also the surface growth $\mathrm{i}, \mathrm{n}_{1}$ 'inly due to the AD 1906 and AD 1944 eruptions but it is not progressive from 1876 to 1)44: in fact, after a consistent increase occurred with the AD 1906 eruption $\left(\sim 0.11 \mathrm{~km}^{2}\right)$, the AD 1929 eruption generated a surface reduction of $\sim 0.08 \mathrm{~km}^{2}$, followed by another increase of $\sim 0.12 \mathrm{~km}^{2}$ that allowed to reach the current value of $\sim 3.87 \mathrm{~km}^{2}$. The volume and surface growths meet the observations derived from the heights profiles (12 for each altimetry model), showing an increase in elevation of at least $40 \mathrm{~m}$ in the Gran Cono flanks, especially in the NW, NE and SE quadrants, and a lowering of the crater bottom of at least $25 \mathrm{~m}$ from $1876(1210 \pm$ $11 \mathrm{~m}$ a.s.l.) to 1944 (970 $\mathrm{m}$ a.s.l.). In addition, the profiles well identify a series of volcanic morphologies related to specific eruptions, in particular: i) the "Colle Margherita" "exhogeneous tholoid" (or "dome-shaped accumulations of the lava flows"), formed during the AD 1891-94 
eruption, is well identified by the profiles crossing the $\mathrm{N}$ quadrants. For this structure, a thickness of around $40 \mathrm{~m}$ is estimated in the N-NW flank of the Gran Cono; ii) the "Hot avalanche" deposits of the AD 1944 eruption, well recognizable in several profiles crossing the NW, NE and SE quadrants, show a thickness of 20-25 m, a value in good agreement with the estimates of Hazlett et al. (1991);

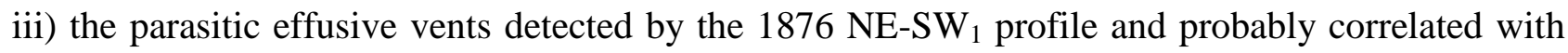
the 1872 vent and with some buried vents (of age unknown). However, the most peculiar changes seem to be referred to the $1906-1929$ period when the Gran Cono increases in volume of $\sim 27 \times 10^{6}$ $\mathrm{m}^{3}$ and, contemporaneously decreases in surface of $0.08 \mathrm{~km}^{2} \mathrm{~T}_{\mathrm{n}}$ 'se changes can be actually justified considering the intra-calderic activity of such period alla producing abundant material, has strongly filled the crater forming also new small cones, and, in particular, has increased the elevation of the crater bottom thus generating a decrerst of the flanks surfaces inside the crater. Also, the crater rim shows significant modificat' 1876 to 1929 (from $0.08 \mathrm{~km}^{2}$ to $0.46 \mathrm{~km}^{2}$ ' fr llowed, during the AD 1944 eruption, by a strong reduction resulting in $\sim 0.24 \mathrm{~km}^{2}$.nd preserved until now. These enlargements are contemporaneous to the progressive NE $r$ gration of the crater centroid of at least $50 \mathrm{~m}$ followed, with the AD 1944 eruption, by a centroid SW migration of at least $170 \mathrm{~m}$. Such migrations, estimated taking into account he errors in $\mathrm{x}$ and $\mathrm{y}$ of source data, occur along the $\mathrm{SW}-\mathrm{NE}$ direction individuated by $l^{-}$ailgnment of the centroids. Such alignment is in agreement with one of the two main deep faults system trend located below Somma -Vesuvio. In conclusion, despite the different typology and accuracy degree of the data source, this study allowed to better document the morphological changes of a portion of the Somma-Vesuvio volcano from 1876 to 1944 , providing quantifications of these changes that, associated to an estimation of error, result in very good agreement with the available literature data. 


\section{Acknowledgments}

We thank the Istituto Geografico Militare and in particular Dr. Marco Bocci for the kind collaboration. We also thank R. Mari from "Città Metropolitana di Napoli - Direzione Strutturazione e Pianificazione dei servizi Pubblici di interesse generale di Ambito Metropolitano Ufficio S.I.T. - Sistema Informativo Territoriale" for kindly providing ALS data for DEM implementation. This work was partly funded by the ClerVolc project - Programme 1 "Detection and characterization of volcanic plumes and ash clouds" fur ded by the French government 'Laboratory of Excellence' initiative. Three anonymous revi we ; are acknowledged for their comments which improved the quality of the manuscript. 


\section{References}

Arrighi, S., Principe, C., and Rosi, M. (2001). Violent strombolian and subplinian eruptions at Vesuvius during post-1631 activity. Bulletin of Volcanology, 63(2-3), 126-150, doi: https://doi.org/10.1007/s004450100130.

Annis, A., Nardi, F., Petroselli, A., Apollonio, C., Arcangeletti, E., Tauro, F., ... \& Grimaldi, S. (2020). UAV-DEMs for Small-Scale Flood Hazard Mapping. Water, 12(6), 1717.

Balletti, C. (2000). Analytical and quantitative methods for the $\sim^{\prime}{ }^{1} y$ sis of the geometrical content of historical cartography. International Archives of Photogra nm.try and Remote Sensing, 33(B5/1; PART 5), 30-37.

Barsotti, S., Neri, A., Bertagnini, A., Cioni, R., Mr'a., M., and Mundula, F. (2015). Dynamics and

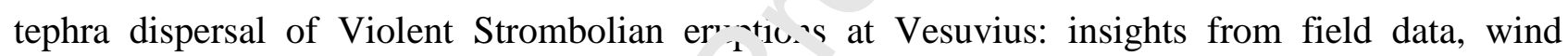
reconstruction and numerical simulation of the 906 event. Bulletin of Volcanology, 77, 1-19.

Bertagnini, A., Landi, P., Santacroce, R, ind Sbrana, A. (1991). The 1906 eruption of Vesuvius: from magmatic to phreatomagmatic a tivity through the flashing of a shallow depth hydrothermal system. Bulletin of Volcanolog, 5\&17), 517-532, doi: https://doi.org/10.1007/BF00298153.

Bertagnini, A., Landi, P., K. si, M., and Vigliargio, A. (1998). The Pomici di Base plinian eruption of Somma-Vesuvius. Journal of Volcanology and Geothermal Research, 83(3-4), 219-239, doi: https://doi.org/10.1016/S0377-0273(98)00025-0.

Bianco, F., M. Castellano, G. Milano, G. Ventura, and G. Vilardo (1998), The Somma- Vesuvius stress field induced by regional tectonics: Evidences from seismological and mesostructural data, $J$. Volcanol. Geotherm. Res., 82(1), 199-218, doi: https://doi.org/10.1016/S0377-0273(97)00065-6

Bisson, M., Pareschi, M.T., Zanchetta, G., Sulpizio, R., Santacroce R. (2007). "Volcaniclastic debris flow occurrences in the Campania region (southern Italy) and their relation to Holocene - 
Late Pleistocene pyroclastic fall deposits: implications for large-scale hazard mapping”, Bulletin of Volcanology, 70, 157-167, doi: 10.1007/s00445-007-0127-4

Bisson, M., Spinetti, C., Neri, M., and Bonforte, A. (2016). Mt. Etna volcano high resolution topography: Airborne Lidar modelling validated by GPS data. International Journal of Digital Earth, 9(7), 710-732, doi: https://doi.org/10.1080/17538947.2015.1119208.

Bisson, M., Paolillo, A., Tadini, A., Sulpizio, R., \& Zanchetta, G. (2018). Volcanoclastic flow hazard assessment in highly populated areas: a GIS-based apprc a $h$ applied to Torre del Greco municipality (Somma-Vesuvius, Italy). Geosciences Journal, 2.2?) , $01-522$.

Bisson M., Tadini A., Gianardi R., \& Angioletti A. (2mn) Morphological Evolution of SommaVesuvio During the Last Century: Integration Betwe en : Yistorical Maps and Airborne LiDAR Survey. In: Parente C., Troisi S., Vettore A. (eds k.':.. Geomatics: Research, Results and Review. R3GEO 2019. Communications in Compuı " ind Information Science, vol 1246. Springer, Cham. https://doi.org/10.1007/978-3-030-62800-๖_?4.

Beyer, R.A, Alexandrov, O., and M $:$ Mıhael, S. (2018). The Ames Stereo Pipeline: NASA's Open Source Software for Deriving a ${ }^{-1} \mathrm{t}$ iocessing Terrain Data. Earth and Space Science, 5(9), 537548, doi: https://doi.org/10. 02:'2018EA000409.

Branca, S., and Abate, T. ( $\angle$ U17). Current knowledge of Etna's flank eruptions (Italy) occurring over the past 2500 years. From the iconographies of the XVII century to modern geological cartography. Journal of Volcanology and Geothermal Research, doi: https://doi.org/10.1016/j.jvolgeores.2017.11.004.

Cappello, A., Vicari, A., \& Del Negro, C. (2011). Assessment and modeling of lava flow hazard on Mt. Etna volcano. Bollettino di Geofisica Teorica e Applicata. 
Cappello, A., Ganci, G., Bilotta, G., Herault, A., Zago, V., \& Del Negro, C. (2018). Satellite-driven modeling approach for monitoring lava flow hazards during the 2017 Etna eruption. Annals of Geophysics.

Cioni, R., Bertagnini, A., Santacroce, R., and Andronico, D. (2008). Explosive activity and eruption scenarios at Somma-Vesuvius (Italy): towards a new classification scheme. Journal of Volcanology and Geothermal Research, 178(3), 331-346, doi: https://doi.org/10.1016/j.jvolgeores.2008.04.024.

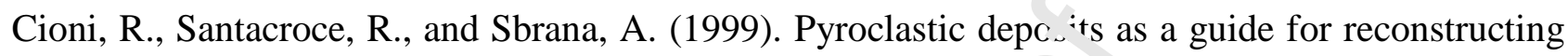
the multi-stage evolution of the Somma-Vesuvius Caldera. Bulle : $_{n}$, f Volcanology, 61(4), 207-222, doi: https://doi.org/10.1007/s004450050272.

Cole, P. D., and Scarpati, C. (2010). The 1944 eruption sf v'suvius, Italy: combining contemporary accounts and field studies for a new volcanolog ca. 'construction. Geological Magazine, 147(3), 391-415, doi: https://doi.org/10.1007/s0044_-7x j0272.

Dai, C., \& Howat, I. M. (2017). Meas'n o Idva flows with ArcticDEM: Application to the 20122013 eruption of Tolbachik, Kamch· tka. Geophysical Research Letters, 44(24), 12-133.

De Beni, E., Cantarero, M., \& Mes sina, A., 2019: UAVs for volcano monitoring: A new approach applied on an active lava ${ }^{{ }^{1}} 0$ Journal of Volcanology ana Geothermal Research, 369, 250-262.

De Leeuw, A. J., Veugen, L. M. M., \& Van Stokkom, H. T. C. (1988). Geometric correction of remotely-sensed imagery usiing ground control points and orthogonal polynomials. International journal of remote sensing, 9(10-11), 1751-1759.

Favalli, M., and Pareschi, M. T. (2004). Digital elevation model construction from structured topographic data: the DEST algorithm. Journal of Geophysical Research: Earth Surface, 109(F4), doi: https://doi.org/10.1029/2004JF000150. 
Favalli, M., Innocenti, F., Teresa Pareschi, M., Pasquarè, G., Mazzarini, F., Branca, S., ... \& Tibaldi, A. (1999). The DEM or Mt. Etna: geomorphological and structural implications. Geodinamica Acta, 12(5), 279-290.

Felpeto, A., Araña, V., Ortiz, R., Astiz, M., \& García, A. (2001). Assessment and modelling of lava flow hazard on Lanzarote (Canary Islands). Natural hazards, 23(2-3), 247-257.

Ferretti, A., Prati, C., \& Rocca, F. (1999). Multibaseline InSAR DEM reconstruction: The wavelet approach. IEEE Transactions on geoscience and remote sensing, 3 , ? ?), 705-715.

Ganci, G., Cappello, A., Bilotta, G., Herault, A., Zago, V, \& Del Negro, C. (2018). Mapping Volcanic Deposits of the 2011-2015 Etna Eruptive Eve $_{1 .}{ }^{+}$S Using Satellite Remote Sensing. Frontiers in Earth Science, 6, 83.

Garvin, J. B., Slayback, D. A., Ferrini, V., F.wıv, J., Giguere, C., Asrar, G. R., \& Andersen, K. (2018). Monitoring and Modeling the Rapid ${ }^{-*}$ olution of Earth's Newest Volcanic Island: Hunga Tonga Hunga Ha'apai (Tonga) Using $H_{11}$, , spatial Resolution Satellite Observations. Geophysical Research Letters, 45(8), 3445-3452 Jwıner, K., Coltelli, M., Flohrera, J., Jaumanna, R., Matza, K. D., Marsella, M., Roatscha, T., ¿ ' hultena, F., and Trauthana, F. (2006). The HRSC-AX Mt. Etna Project: High-resolution $\mathrm{O}$ tho, nages and $1 \mathrm{~m}$ DEM at Regional Scale. In Proceedings ISPRS XXXVI, T05-23 (Part 1).

Hazlett, R. W., Buesch, D., Anderson, J. L., Elan, R., and Scandone, R. (1991). Geology, failure conditions, and implications of seismogenic avalanches of the 1944 eruption at Vesuvius, Italy. Journal of Volcanology and Geothermal Research, 47(3-4), 249-264, doi: https://doi.org/10.1016/0377-0273(91)90004-J.

Huggel, C., Schneider, D., Miranda, P. J., Granados, H. D., \& Kääb, A. (2008). Evaluation of ASTER and SRTM DEM data for lahar modeling: a case study on lahars from Popocatépetl Volcano, Mexico. Journal of Volcanology and Geothermal Research, 170(1-2), 99-110. 
Imbò, G. (1949). Considerazioni sulla presente attività del Vesuvio. Bulletin Volcanologique, 8, 123-132, doi: https://doi.org/10.1007/BF02596785

ISTAT (2011), Censimento popolazione 2011, Istituto Nazionale di Statistica, Database accessed March 2015.

James, M. R., \& Robson, S. (2012). Straightforward reconstruction of 3D surfaces and topography with a camera: Accuracy and geoscience application. Journal of Geophysical Research: Earth Surface, 117 (F3).

Jones, L. K., Kyle, P. R., Oppenheimer, C., Frechette, J. D., ' c L'al, M. H. (2015). Terrestrial laser scanning observations of geomorphic changes and var:ing lava lake levels at Erebus volcano, Antarctica. Journal of Volcanology and Geothermal Re ear.h, 295, 43-54.

Marsella, M., Baldi, P., Coltelli, M., \& $\mathrm{Fa}^{2}$ ¿s, M. (2012). The morphological evolution of the Sciara del Fuoco since 1868: reconstructing th - effusive activity at Stromboli volcano. Bulletin of Volcanology, 74(1), 231-248.

Müller, D., Walter, T. R., Schön ı, t. Witt, T., Steinke, B., Gudmundsson, M. T., \& Dürig, T. (2017). High-resolution digitai elevation modeling from TLS and UAV campaign reveals structural complexity at the 2014/ $\mathrm{A}^{\top 1} \mathrm{~S}$ Ur iuhraun eruption site, Iceland. Frontiers in Earth Science, 5, 59.

Naddeo, B. A. (2004). Topographies of Difference: Cartography of the City of Naples, 1627-1775. Imago Mundi, 56(1), 23-47, doi: https://doi.org/10.1080/0308569032000172932.

Neri, M., Mazzarini, F., Tarquini, S., Bisson, M., Isola, I., Behncke, B., and Pareschi, M.T. (2008). Topographic Map of the Summit Craters of Mount Etna from The changing face of Mount Etna's summit area documented with Lidar technology. Geophysical Research Letters, vol. 35, L09305, doi:10.1029/2008GL033740 
Palmentieri, S. (2016). La cartografia storica per l'analisi dell'evoluzione funzionale delle ville vesuviana. Bollettino della Associazione Italiana di Cartografia, 158, 120-130, doi: $10.13137 / 2282-572 X / 20336$.

Pesci, A., Fabris, M., Conforti, D., Loddo, F., Baldi, P., \& Anzidei, M. (2007). Integration of ground-based laser scanner and aerial digital photogrammetry for topographic modelling of Vesuvio volcano. Journal of Volcanology and Geothermal Research, 162(3-4), 123-138

Pizzimenti, L., Tadini, A., Gianardi, R., Spinetti, C., Bisson, M., a.^ Brunori, C. A. (2016). Digital Elevation Models derived by ALS data: Sorrentina Peninsula ‘st areas. Rapporti tecnici INGV, $\mathrm{n}^{\circ} 361$.

Principe, C., Tanguy, J. C., Arrighi, S., Paiotti, A., Le Csoti, M., and Zoppi, U. (2004). Chronology of Vesuvius' activity from AD 79 to 1631 ba sec $n_{1}$ archeomagnetism of lavas and historical sources. Bulletin of Volcanology, 66(8), 70, 7`24, doi: https://doi.org/10.1007/s00445-004-0348-8.

Ronza, M. (2017). Ville e processi di ur ja .iz:zazione: la collina del Vomero nella città di Napoli. La

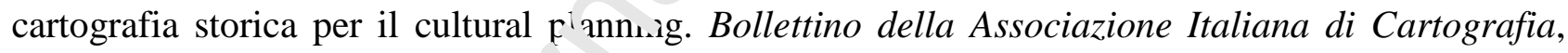
159, 54-68, doi: 10.13137/2282-j72 $\mathbf{s} / 20559$.

Rosi, M., Principe, C., a. d Ter ci, R. (1993). The 1631 Vesuvius eruption. A reconstruction based on historical and stratigrapnical data. Journal of Volcanology and Geothermal Research, 58(1), 151-182, doi: https://doi.org/10.1016/0377-0273(93)90106-2.

Santacroce, R. and Sbrana, A. (2003). The Vesuvius geological map, CARG project. Geological Survey of Italy. Editor: SELCA Firenze.

Santacroce, R., Cioni, R., Marianelli, P., Sbrana, A., Sulpizio, R., Zanchetta, G., Donahue, D. J. and Joron, J. L. (2008). Age and whole rock-glass compositions of proximal pyroclastics from the major explosive eruptions of Somma-Vesuvius: A review as a tool for distal 
tephrostratigraphy. Journal of Volcanology and Geothermal Research,177(1), 1-18, doi: https://doi.org/10.1016/j.jvolgeores.2008.06.009.

Sbrana, A., Cioni, R., Marianelli, P., Sulpizio, R., Andronico, D., and Pasquini, G. (2020). Volcanic evolution of the Somma-Vesuvius Complex (Italy). Journal of Maps, 1-11, doi: https://doi.org/10.1080/17445647.2019.1706653.

Scandone, R., Giacomelli, L., and Gasparini, P. (1993). Mount Vesuvius: 2000 years of volcanological observations. Journal of Volcanology and Geotheınal Research, 58(1), 5-25, doi https://doi.org/10.1016/0377-0273(93)90099-D.

Scandone, R., Giacomelli, L., and Speranza, F. F. (2008) nel $_{\mathbf{L}}$ 'stent activity and violent strombolian eruptions at Vesuvius between 1631 and 1944. Journa' of 'olcanology and Geothermal Research, 170(3-4), 167-180, doi: https://doi.org/10.1016/j. vw__̌ores.2007.09.014.

Salvatici, T., Di Roberto, A., Di Traglia, F., L sson, M., Morelli, S., Fidolini, F., ... \& Casagli, N. (2016). From hot rocks to glowing ava'dl hes: numerical modelling of gravity-induced pyroclastic density currents and hazard maps at he stromboli Volcano (Italy). Geomorphology, 273, 93-106.

Shewchuk, J. R. (2002). L गlau ıay refinement algorithms for triangular mesh generation.

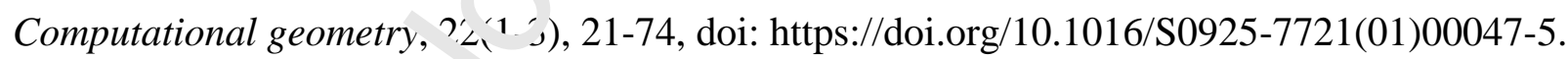

Sigurdsson, H., Carey, S. N., Cornell, W., and Pescatore, T. (1985). The eruption of Vesuvius in AD 79. National Geographic Research, 1(3), 332-387.

Tadini, A., Bisson, M., Neri, A., Cioni, R., Bevilacqua, A., and Aspinall, W. P. (2017). Assessing future vent opening locations at the Somma- Vesuvio volcanic complex: 1. A new information geodatabase with uncertainty characterizations. Journal of Geophysical Research: Solid Earth, 122(6), 4336-4356, doi: https://doi.org/10.1002/2016JB013858. 
Tarquini, S., Isola, I., Favalli, M., Mazzarini, F., Bisson, M., Pareschi, M. T., and Boschi, E. (2007). TINITALY/01: a new triangular irregular network of Italy. Annals of Geophysics, 50(3), doi: http://hdl.handle.net/2122/3673.

Tramparulo, F. D. A., Vitale, S., Isaia, R., Tadini, A., Bisson, M., \& Prinzi, E. P. (2018). Relation between alternating open/closed-conduit conditions and deformation patterns: An example from the Somma-Vesuvius volcano (southern Italy). Journal of Structural Geology, 112, 138-153.

Travaglini, D. (2004). Trasformazioni tra sistemi di coordinatc. software disponibili, limiti e potenzialità. Forest@-Journal of Silviculture and Fores._Ecology, 1, 128-134, doi: 10.3832/efor0228-0010128.

Ventura, G., and Vilardo, G. (2008). Emplacement mer has: ${ }^{\circ}$ of gravity flows inferred from high resolution Lidar data: The 1944 Somma-Vesuvil s ı.^flow (Italy). Geomorphology, 95(3-4), 223235, doi: https://doi.org/10.1016/j.geomorp. Tr, J7.06.005.

Whelley, P. L., Garry, W. B., Hamiltor,. W., and Bleacher, J. E. (2017). LiDAR-derived surface roughness signatures of basaltic liva ıpes at the Muliwai a Pele Lava Channel, Mauna Ulu, Hawaii”. Bulletin of Volcanology, 7乌i11), 75, doi: https://doi.org/10.1007/s00445-017-1161-5.

Wu, S. S. (1979). Ph屯'ng ar metric portrayal of Mars topography. Journal of Geophysical Research: Solid Earth, 84(ธ14), 7955-7959. 
Declaration of competing interest

The authors declare that they have no known competing financial interests or personal relationships that could have appeared to influence the work reported in this paper. 


\section{Highlights}

- A morphometric study of Somma-Vesuvio caldera is presented for 1876 - 1944 period

- Past and recent topographies are reconstructed from historical maps and ALS data

- The analyses are based on height profiles, volume and distance quantifications

- The quantifications of the morphological changes are associated to error estimations

- Reliable morphological quantitative data are derived from historical cartography 